Mixed and Detrital Marginal Facies 



\title{
LOWSTAND PROGRADING WEDGES AS FOURTH-ORDER GLACIO-EUSTATIC CYCLES IN THE PLEISTOCENE CONTINENTAL SHELF OF APULIA (SOUTHERN ITALY)
}

\author{
GEMMA AIELLO AND FRANCESCA BUDILLON \\ Istituto per l'Ambiente Marino Costiero, Geomare, National Research Council, \\ Calata Porta di Massa, Porto di Napoli, 80133 Napoli, Italy \\ e-mail: aiello@gms01.geomare.na.cnr.it
}

\begin{abstract}
Aвstract: The Salento continental shelf of Apulia (southern Adriatic) shows a complex stratigraphic architecture of Pleistocene prograding wedges that records the effects of the interplay of sediment accumulation, glacio-eustatic sea level changes, and regional tectonics. The interpretation of high-resolution seismic reflection profiles reveals three ravinement surfaces, extending landwards from the shelf break and showing low gradients. They have been considered to be stratigraphic markers and tentatively correlated to the oxygen curves of the isotopic stratigraphy. Even if direct dating of seismic sequences and corresponding unconformities is lacking, this correlation is well supported by the lateral extent and continuity of the ravinement surfaces, recognized in the whole investigated area. Similar qualitative correlation of unconformities with the curves of oxygen-isotope stratigraphy has been already used by other authors in different case histories of continental shelves of both active and passive margins. Moreover, in the study area the regional geological framework suggests that during the Middle Pleistocene the rate of tectonic uplift interacted with the rate of glacio-eustatic fluctuations, producing the deposition of forced-regression systems tracts. The forced-regression prograding wedge that enlarged the shelf by about fifteen kilometers is here dated as Middle Pleistocene. Starting from the upper part of the Middle Pleistocene, the stratigraphic architecture of the prograding wedges was controlled mainly by glacio-eustatic sea-level changes forced by short-eccentricity cycles. This is suggested by the stratigraphic architecture of the last two prograding wedges, interpreted as incomplete fourth-order depositional sequences and consisting of forcedregression, lowstand, and transgressive systems tracts. The eustatic signal as an expression of the Earth's orbital cyclicity (short eccentricity) appears overwhelming with respect to the tectonic one, and its prominence suggests a decrease in the rate of uplift of the Apulian foreland during the last $250 \mathrm{ky}$.
\end{abstract}

\section{INTRODUCTION}

Recent studies carried out on active and passive margins show that the stratigraphic architecture of the continental shelves consists mostly of lowstand, shelf-margin, and transgressive system tracts deposits (Suter and Berryhill, 1985; Suter et al., 1987; Saito, 1991; Tesson et al., 1990; Tesson et al., 1993; Okamura and Blum, 1993; Trincardi and Correggiari, 2000). Highstand deposits form mainly on the inner shelf, where they appear as thick wedges thinning significantly basinwards. Moreover, in the outer shelf, the preservation of highstand deposits is often difficult, due to the erosive action induced by emersions and wave currents. On the inner shelf, relative sea-level falls, subsequent to phases of rising, often cause partial erosion of highstand deposits, along with sediment reworking in the coastal areas (Field and Trincardi, 1992; Gensous et al., 1993).

Isotopic analysis of deep-sea sediments and corals (Bard et al., 1990a; Bard et al., 1990b) shows that, during the Pleistocene, glacio-eustatic changes clearly exhibit high-frequency (about 100 ky) oscillations; cycles are highly asymmetrical, showing rapid rises and slow falls of the sea level (Shackleton and Opdyke, 1973; Martinson et al., 1987). The stratigraphic architecture of Pleistocene continental margins is characterized by a relative abundance of lowstand prograding wedges with respect to transgressive and highstand deposits, as is well known in the Mediterranean region (Trincardi and Field, 1991; Tesson et al., 1993; Chiocci et al., 1997; Catalano et al., 1998). Shelf sediments, deposited during Pleistocene glacio-eustatic cycles, accumulated on the outer shelf and upper slope during subaerial exposures and formed thick sedimentary wedges (shelf-perched lowstand wedges; Posamentier and Vail, 1988).

The aim of this paper is to discuss the role of fourth-order glacio-eustasy sensu Vail et al. (1991) vs. regional tectonics in controlling the stacking patterns of lowstand prograding wedges and their cyclicity. In the study area the Apulia (Puglia) shelf shows a Middle-Late Pleistocene stratigraphic record with seismic reflectors of high lateral continuity, being part of a relatively undeformed area ("Apulian foreland"; Fig. 1; D'Argenio et al., 1973; Ricchetti et al., 1992). In this area the methods of sequence stratigraphy (Mitchum et al., 1977; Posamentier and Vail, 1988; Posamentier et al., 1992) can easily be applied in the interpretation of seismic sections.

High-resolution reflection seismic profiles (Sparker $1 \mathrm{~kJ}$ seismic source) analyzed in this paper were recorded in 1994, during the GMS94-01 cruise, carried out by the Geomare Sud Research Institute, National Research Council, Naples, Italy, on the R/V Urania (Aiello et al., 1994, 1995; Budillon and Aiello, 1999). The study area (Fig. 2) is located in the southernmost sector of the continental shelf of the southern Adriatic sea (Fig. 1), offshore of the Apulia region. The investigated area is located offshore of the Salento Peninsula between Capo d'Otranto and Capo S. Maria di Leuca (Fig. 1). The seismic grid, covering an area of about 1200 $\mathrm{km}^{2}$, consists of NW-SE and NE-SW oriented seismic profiles (line LC8; line LC9; line LC10; line LC11; Fig. 2) and of two regional seismic profiles (line LC4-5 and line LC1-2; Fig. 2) recorded in order to provide crossing points with the other lines. The seismic grid is located mostly in water depths ranging between the $-50 \mathrm{~m}$ and $-200 \mathrm{~m}$ isobaths (Fig. 2). Two E-W oriented seismic profiles (line LC7 and line LC12; Fig. 2) were acquired off Capo d'Otranto and Capo S. Maria di Leuca, respectively, (Figs. 1, 2). The resolution of Sparker $1 \mathrm{~kJ}$ profiles is about $3 \mathrm{~m}$; the seismic sections have a penetration corresponding to a vertical scale of $0.5 \mathrm{~s}$.

\section{GEOLOGIC SETTING}

The Salento continental shelf is part of the Apulia foreland (Fig. 1), which corresponds to a wide antiformal structure, WNW- 


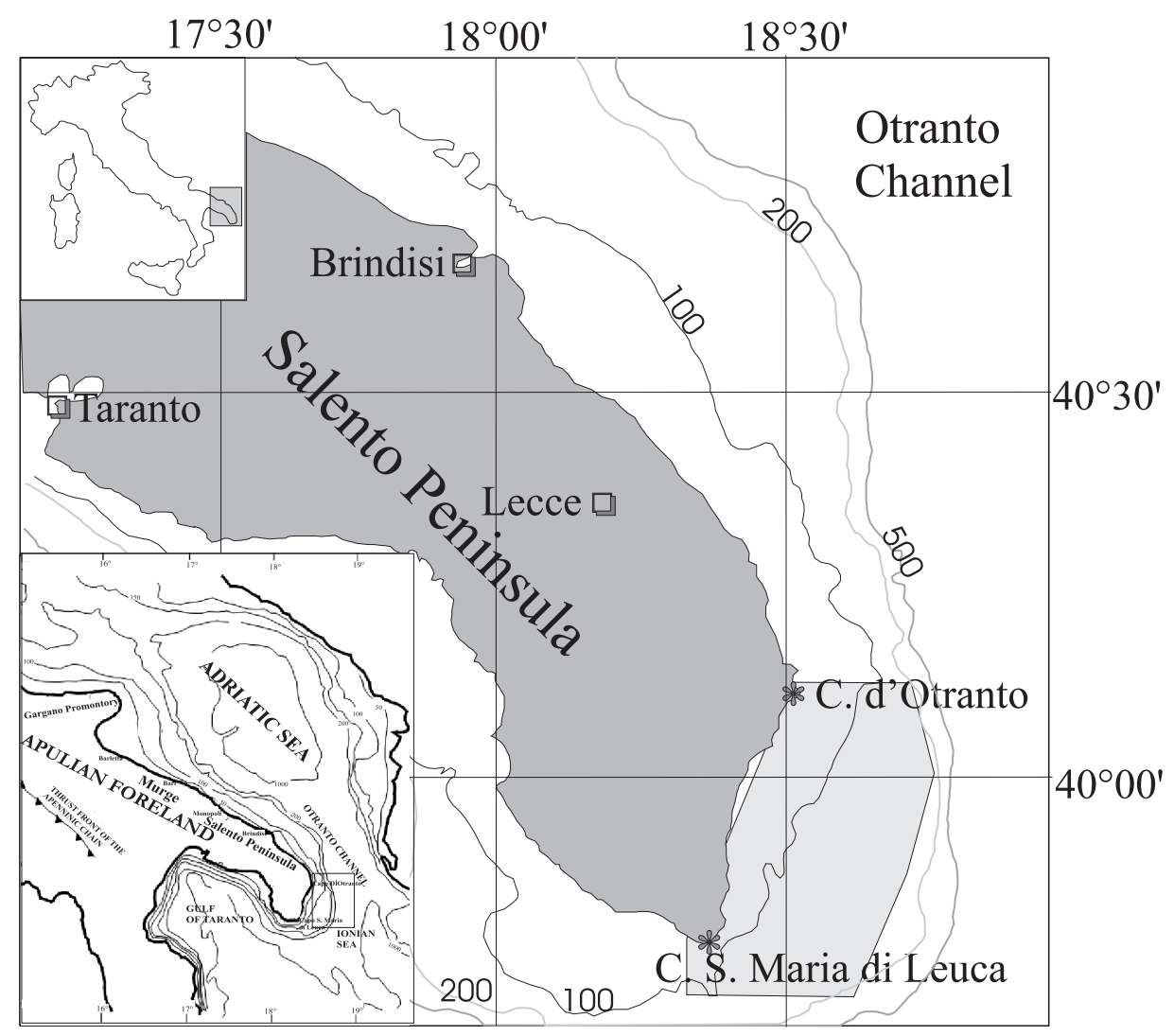

FIG. 1. - Study area in its regional frame: the southern Adriatic Sea and the foreland of the Southern Apennines chain (Apulia). The locations of the Gargano Promontory, the Murge region, and the Salento Peninsula are also shown. The triangles separate the front of the Southern Apennines fold-and-thrust belt from the foredeep system.

ESE trending, block-faulted, and variably uplifted during late Neogenic times (Ricchetti et al., 1992). Transfer faults, striking oblique or perpendicular to the main antiformal structure, segmented the Apulia into three main blocks (Gargano, Murge, and Salento blocks; Fig. 1), which had different rates of uplift during the Plio-Pleistocene, when the central Adriatic Sea underwent high subsidence rates, interpreted as the effect of the eastward rollback of the hinge of the west-dipping Apenninic subduction zone (Doglioni et al., 1994).

The occurrence of regressive sedimentary sequences, overlying erosional surfaces, suggests a uniform uplift of the Murge and Salento blocks after the Middle Pleistocene (Fig. 1), also supported by the regional distribution of the fossil shorelines (Cosentino and Gliozzi, 1992). The eustatic sea-level oscillations and tectonic uplift have produced various terraces, reaching even $200 \mathrm{~m}$ above sea level (Ciaranfi et al., 1992; Cosentino and Gliozzi, 1992; Ricchetti et al., 1992). Average values of about 0.23 $\mathrm{m} / \mathrm{ky}$ have been suggested for the rate of uplift of the Salento Peninsula during the Late Pleistocene, on the basis of the age of the Tyrrhenian deposits (Hearty and Dai Pra, 1992; Cosentino and Gliozzi, 1992).

Previous studies of the geology of the southern Salento Peninsula (Bossio et al., 1988; Ricchetti et al., 1992) recognize carbonate stratal packages in the onshore sector of the investigated area (Figs. 1,2). These rocks, shown in the geological sketch map in Figure 3, range in age from the Middle-Late Miocene (Calcareniti di Andrano Formation; Langhian to Tortonian; no. 3 in Fig. 3) to the Pleistocene (Calcareniti del
Salento Formation; no. 1 in Fig. 3). Their substrate, cropping out widely in the mainland, is represented by Upper Cretaceous limestones and dolomitic limestones (Calcare di Altamura Formation; no. 5 in Fig. 3), overlain unconformably by bioclastic limestones, Paleocene-Oligocene in age (Calcari di Castro and Calcareniti di Porto Badisco formations; no. 4 in Fig. 3). The Mesozoic-Cenozoic deposits cropping out in the Salento Peninsula were eroded during phases of tectonic uplift of the foreland, supplying sediments for the deposition of the lowstand prograding wedges discussed in this paper. The geologic map in Figure 3 also gives some information on the offshore area based on the interpretation of the seismic profiles (see the subsequent description of the seismic units and the interpretation of data). This map shows the main outcrops of the basal unit, which forms the substrate of the Pleistocene prograding wedges on land and at the sea bottom, bounded seawards by normal faults. In Figure 3 the main axis of antiformal and synformal structures, involving the Middle-Late Pleistocene prograding wedges, and the trends of the ravinement surfaces RS1, RS2, and RS3 are also represented.

\section{DESCRIPTION OF SEISMIC UNITS}

The stratigraphic architecture of the Salento continental shelf is characterized by thick prograding wedges unconformably overlying a basal unit, forming a substrate over which progradation of the platform occurred during the Pleistocene (Fig. 4). This basal unit crops out close to the coastline, where it is bounded 


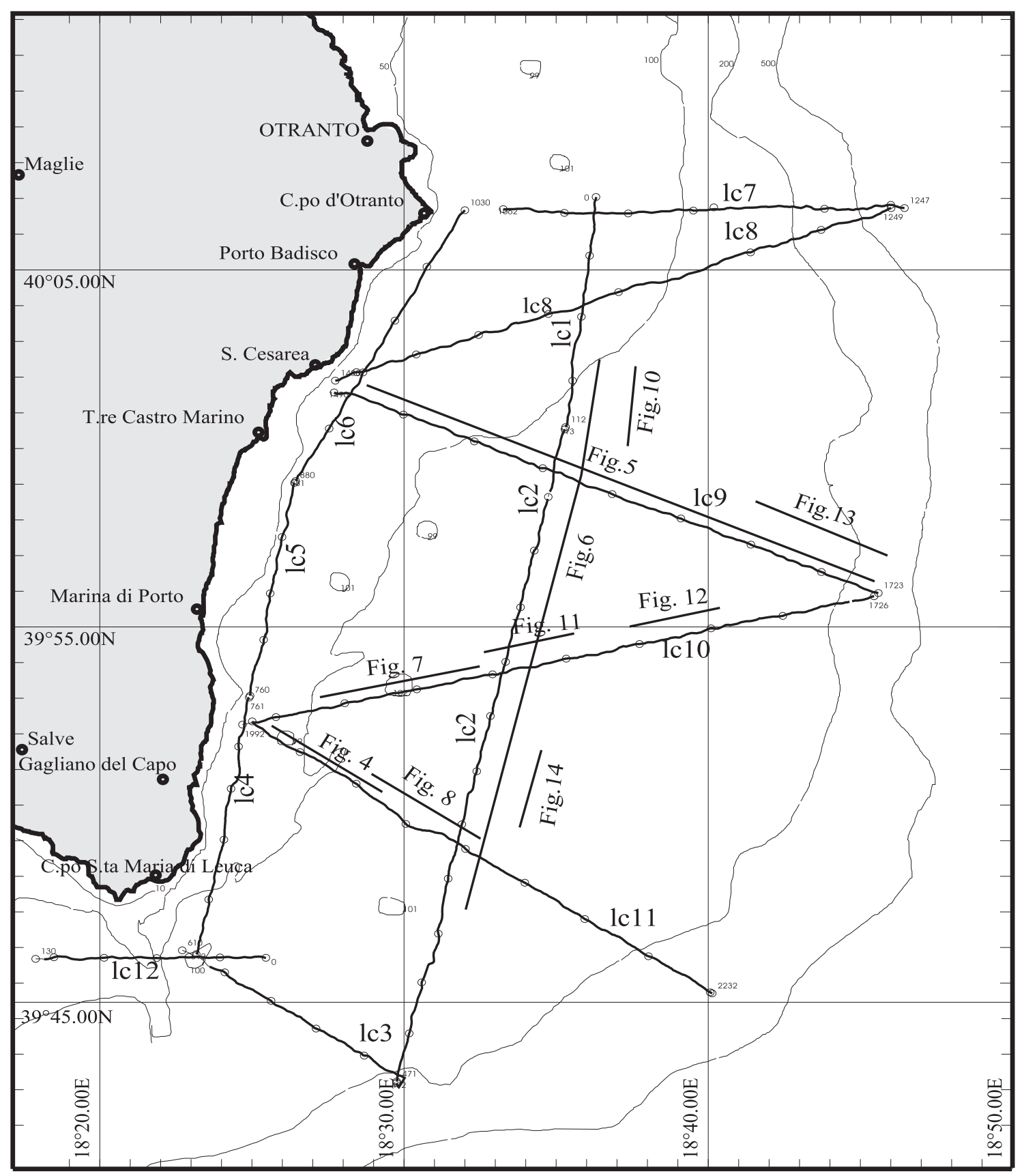

FIG. 2.-Seismic grid of Sparker $1 \mathrm{~kJ}$ profiles analyzed in this paper (see the text for further details).

seawards by normal faults (Fig. 3) and correlates to the units forming the present-day coastal cliffs (Fig. 3; Aiello et al., 1995; Budillon and Aiello, 1999).

The coastal cliffs are formed by the Calcari di Castro and Calcareniti di Porto Badisco formations (Paleocene to Oligocene in age; Fig. 3) and by the "Calcareniti di Andrano" Formation (Langhian to Tortonian; Fig. 3). The seismic expression of the basal unit shows a complex morphostructural evolution. This unit, characterized by a chaotic acoustic facies (Fig. 4), is overlain by several erosional surfaces, probably formed above sea level (Fig. 4; Aiello et al., 1995; Budillon and Aiello, 1999).

\section{Seismic Units}

Depositional geometries and stratal patterns of seismic units are described below, as shown by the interpretation of two regional seismic profiles, located parallel and perpendicular to the coastline between Otranto and S. Maria di Leuca, respectively (line LC9 and line LC1-2, in Figs. 5 and 6, respectively). Good control of seismic reflectors and unconformities at the crossing points between the two profiles (Figs. 5 and 6) provided a reliable stratigraphic interpretation of Pleistocene prograding wedges based on seismic stratigraphy criteria (Mitchum et al., 1977; Vail et al., 1991). Another regional seismic profile (line LC10) is shown 


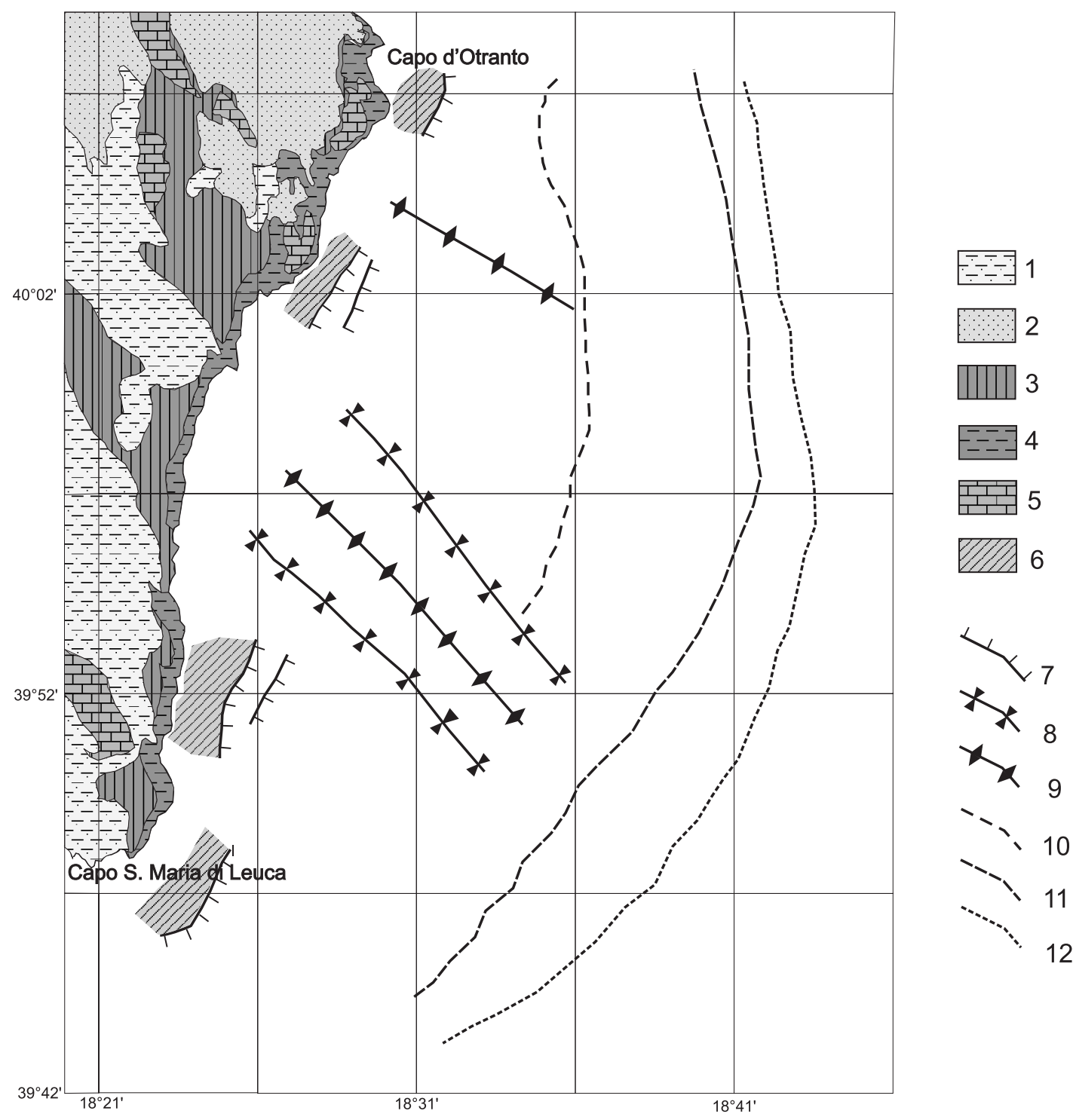

FIG. 3.-Simplified geologic map of the Salento Peninsula (see Fig. 1 for location). Onshore geology is from National Geological Survey of Italy, Geological Map 1:100.000, no. 223 "Capo S. Maria di Leuca". Axes of antiformal and synformal structures involving Pleistocene prograding wedges, and normal faults bounding seaward outcrops of the basal unit located in the inner shelf, have also been reported. Trends of the ravinement surfaces RS1, RS2, and RS3, related to the Pleistocene prograding wedges, show that the shelf progradation in the Salento offshore is on the order of several kilometers. Legend: 1 , calcarenites, bioclastic limestones, and calcareous sands (Calcareniti del Salento Formation; Pleistocene); 2, calcareous sands and marly calcarenites (Sabbie di Uggiano La Chiesa Formation; Early Pliocene); 3, organogenic calcarenites (Calcareniti di Andrano Formation; Langhian to Tortonian); 4, bioclastic limestones (Calcari di Castro and Calcareniti di Porto Badisco Formations; Paleocene to Oligocene); 5, limestones and dolomitic limestones (Calcare di Altamura Formation; Upper Cretaceous); 6, outcrops of the basal unit $\mathrm{AB}$ at the sea bottom (Upper Cretaceous to Paleocene; Upper Cretaceous to Oligocene); 7, normal faults; 8, synform axes; 9 , antiform axes; 10, paleo-shelf break of ravinement surface RS1; 11, paleoshelf break of ravinement surface RS2; 12, paleo-shelf break of ravinement surface RS3.

in Figure 7 in order to give further information on the stratigraphic framework of the area.

Details of critical segments of the seismic lines are shown in Figures 4 and 8 and in Figures 10 to 14, as follows:

AB: basal unit. It is characterized by chaotic seismic facies (Fig. 4). Landwards it is bounded by subaerial unconformities (Fig. 4), and basinwards it shows relationships of paraconformity with the overlying unit U1 (Fig. 8). The main outcrops of the basal unit are located close to the coastline and are bounded seawards by normal faults (Fig. 3). The basal unit correlates to the rocks forming the presentday coastal cliffs, i.e., the Calcari di Castro and Calcareniti di Porto Badisco formations (Paleocene to Oligocene) and the Calcareniti di Andrano Formation (Langhian to Tortonian). 


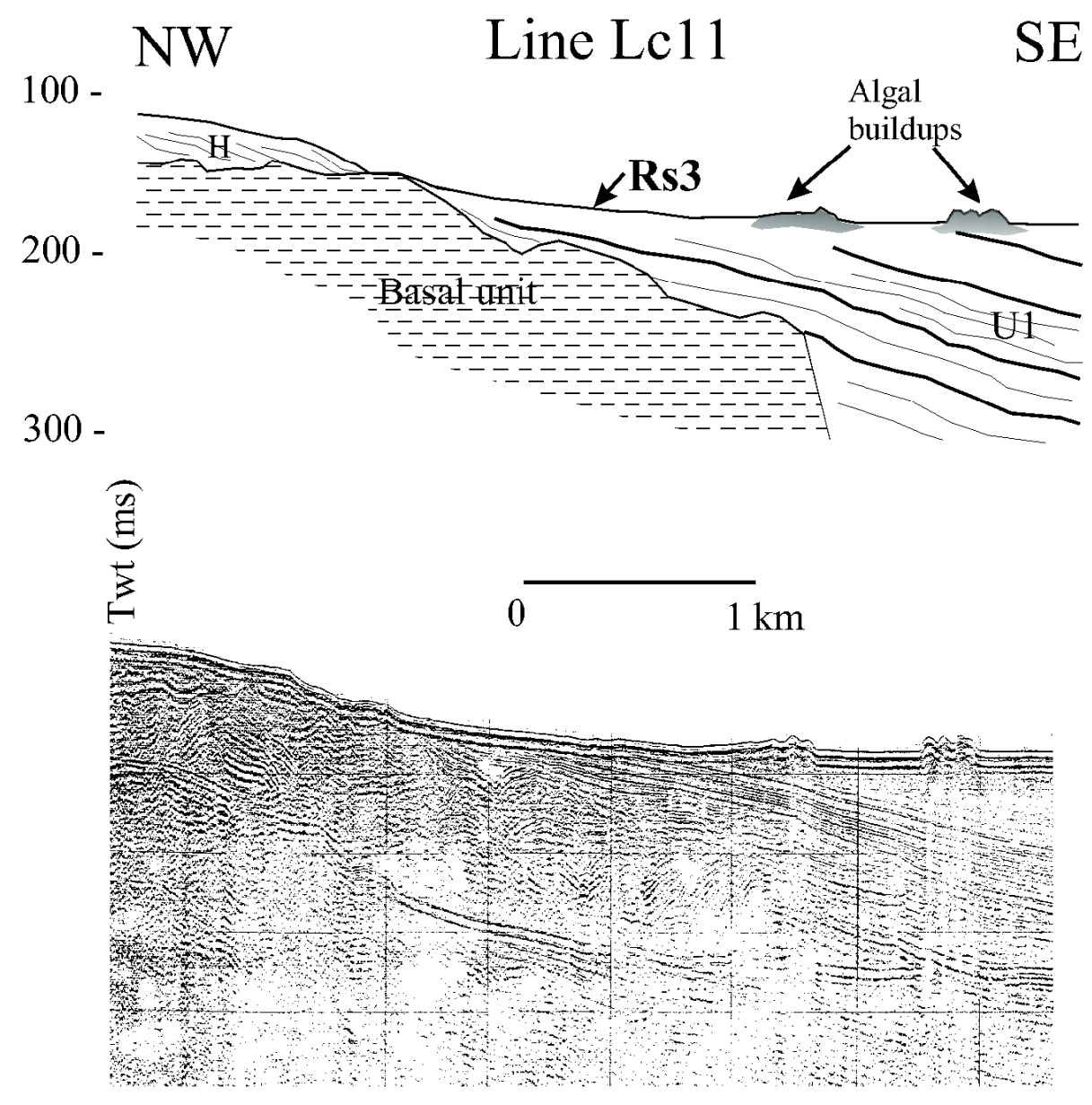

FIG. 4.-Seismic profile LC11 (see Fig. 2 for location), showing the basal unit (AB on the left in the profile), characterized by a chaotic seismic facies and slightly deformed by normal faulting. The unit crops out close to the coastline (see also Fig. 3) and correlates with Paleocene to Oligocene limestones and Middle-Late Miocene calcarenites cropping out in the coastal cliffs of the Salento Peninsula (Fig. 3). Unit AB is unconformably overlain by a Pleistocene prograding wedge (seismic unit U1, on the right of the profile; see the text and Fig. 8 for further details).

U1: This seismic unit is characterized by alternations of reflector packages with high amplitude and coherence and of acoustically transparent intervals (Fig. 8). Such a seismic facies suggests the alternation of coarse-grained deposits (corresponding to the transparent intervals) and finegrained sediments (reflectors with high amplitude; Fig. $8)$. In the lower part of the unit the prograding clinoforms show a more pronounced aggradational component, whereas progradational geometries prevail in the upper part (Fig. 8). Seismic profiles show a paraconformity between the unit $\mathrm{U} 1$ and the underlying unit AB (Fig. 6). The prograding clinoforms of the unit U1 are truncated near the sea bottom by the ravinement surface RS3 (Figs. 7,8).

As shown by the regional profile LC1-2 (Figs. 6, 9), Unit $\mathrm{U} 1$ is affected by compressional deformation, forming large antiformal and synformal structures, whose axes are represented in plan view in Figure 3. These structures also affect Units $\mathrm{U} 2, \mathrm{U} 3$, and $\mathrm{U} 4$ and represent the seaward extension of compressional trends documented in the Salento Peninsula (Bossio et al., 1988). The antiforms are cut by normal faults (Figs. 6, 7). The ravinement surface RS1 and the unit U5 cut the antiforms and the synforms probably at the end of the Middle Pleistocene (Fig. 6).

U2: This seismic unit shows continuous reflectors overlying the structural highs with onlap terminations, as shown by the regional profile LC1-2 (Figs. 6, 9) and by its details (Fig. 10), as well as by the downlap geometries at the top of the underlying unit U1 (Fig. 11).

U3: This seismic unit shows acoustic facies characterized by high amplitude and low lateral continuity, with an aggradational component particularly evident in the N-S direction (Fig. 6).

U4: seismic unit thinning rapidly onto the structural highs (Fig. 6) with onlap geometries on the ravinement surface RS1 (Fig. 12).

U5: seismic unit onlapping the erosional surface RS1 (Fig. 12) and thinning laterally (along strike) with downlap geometries (Fig. 6). 


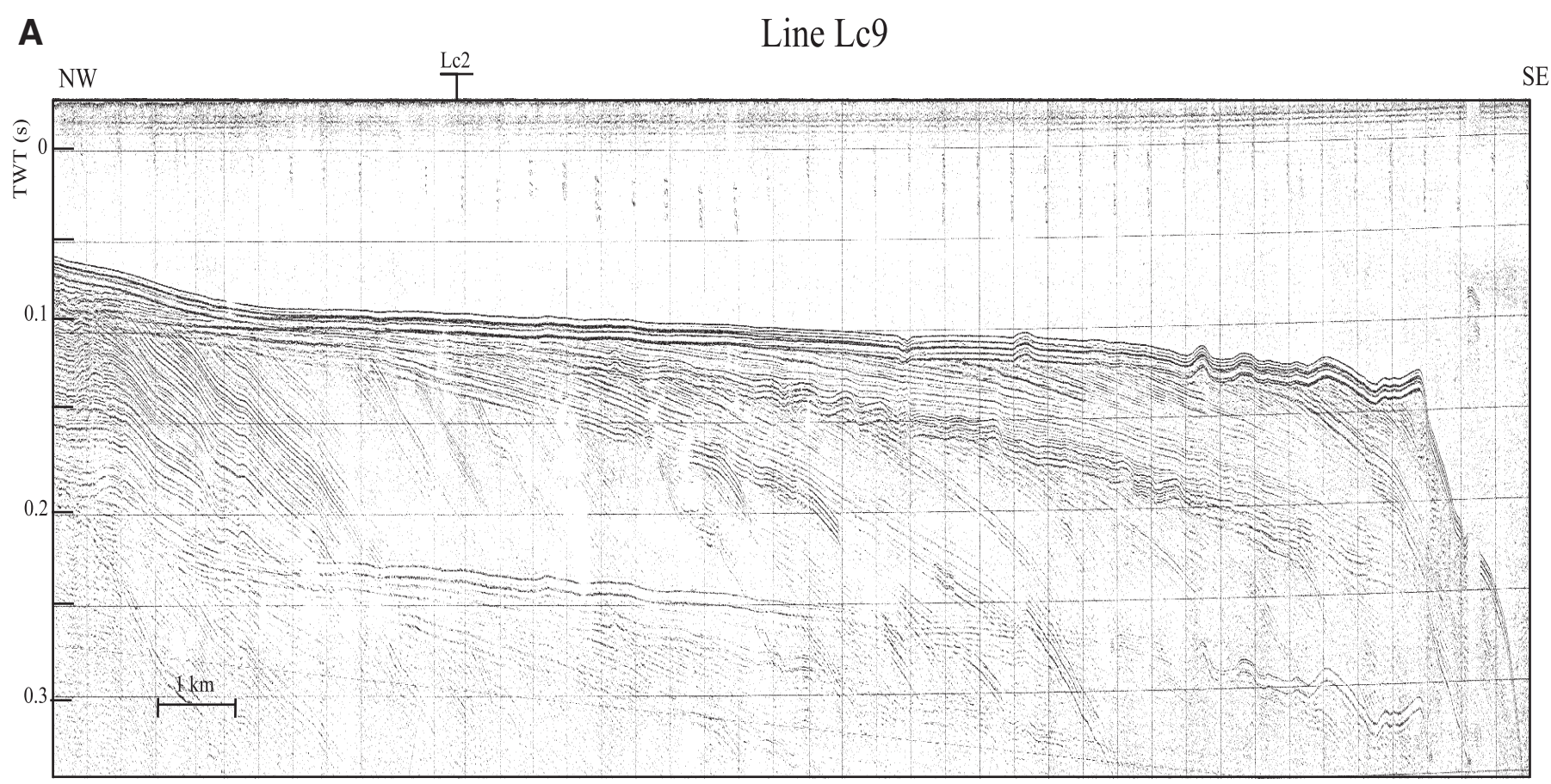

\section{B}

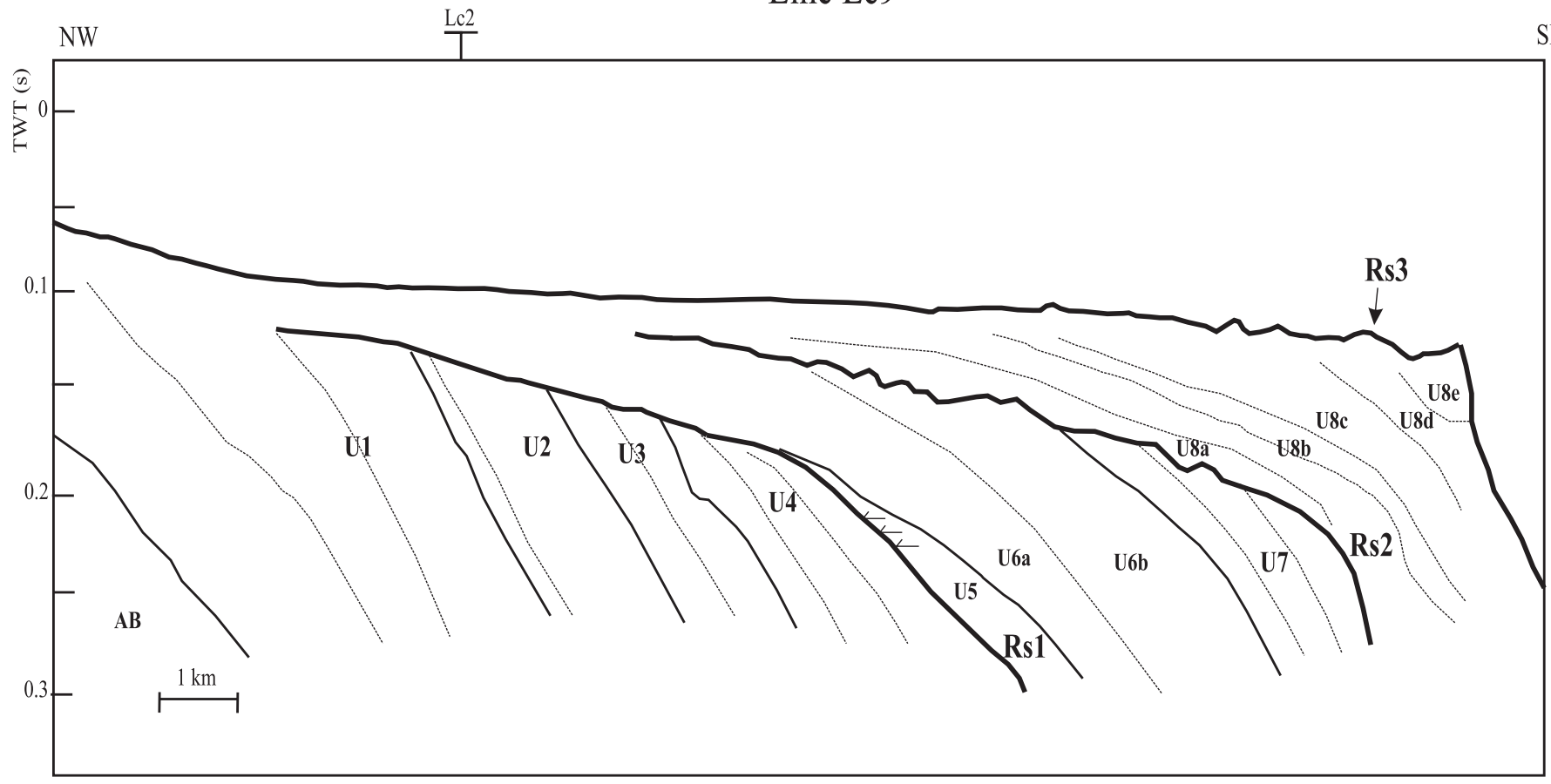

FIG. 5.-A) Seismic profile LC9 (see Fig. 2 for its location) and B) corresponding interpretation. The seismic profile and its interpretation show the Pleistocene prograding wedges of the Salento continental shelf, overlying an acoustic basement (unit AB; see also Figs. 4 and 7) and the stratigraphic relationships between the ravinement surfaces and the seismic units. The Middle Pleistocene prograding wedge is characterized by two episodes of forced regression, separated by a phase of marine ingression, evidenced by ravinement surface RS1 and by seismic unit U5. The units of forced regression are interpreted on the basis of the erosional truncations of internal reflections, as well as of the seaward shifting of the offlap breaks and of the occurrence of chaotic seismic facies suggesting mass transport at the shelf margin. 

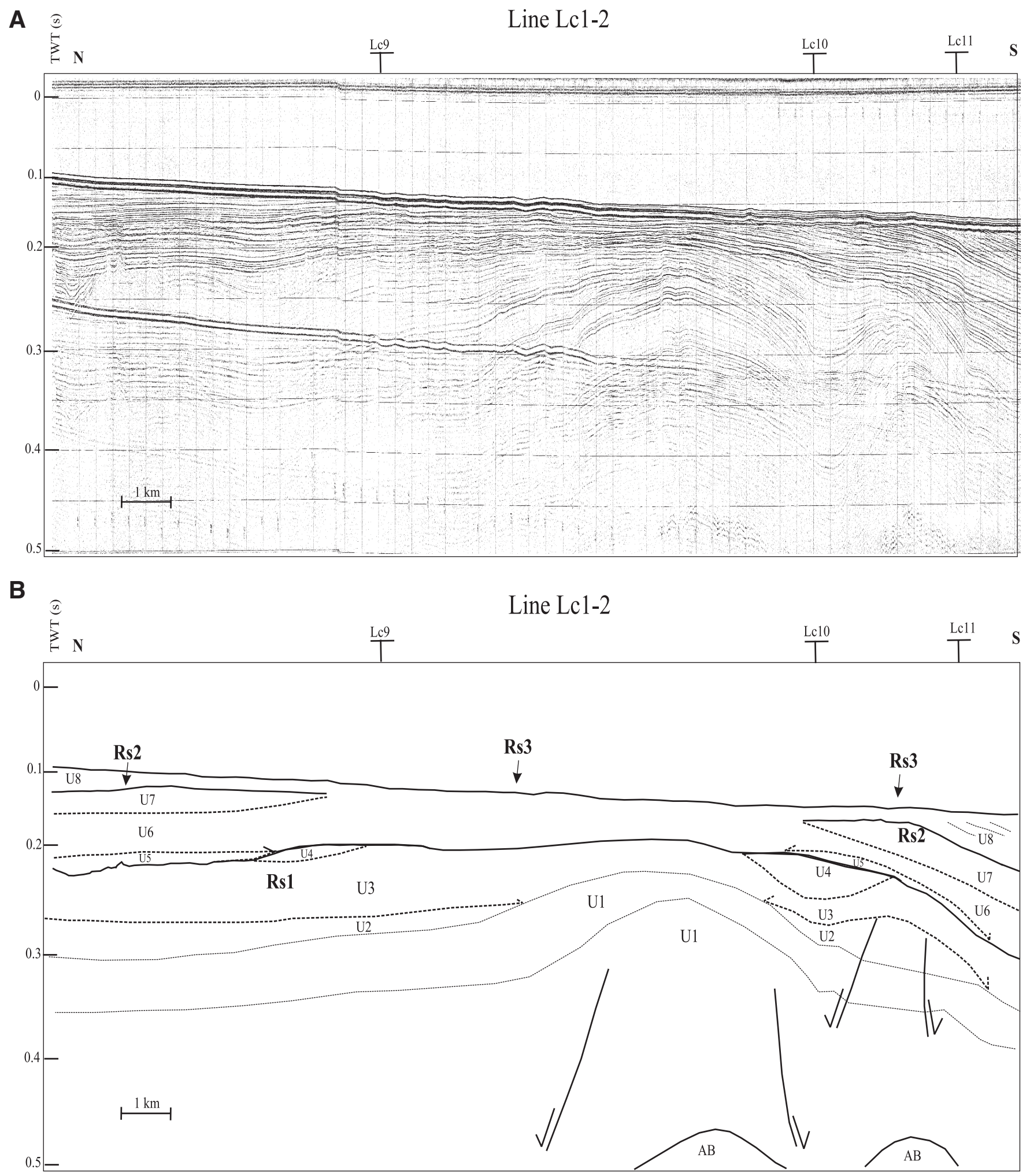

FIG. 6.-A) Seismic profile LC1-LC2 (see Fig. 2 for its location) and B) corresponding interpretation. Seismic units and ravinement surfaces were also interpreted on the basis of the crossing points with the line LC9 (Fig. 5) and with the perpendicular lines. The seismic profile and its interpretation show antiformal and synformal structures affecting units U1, U2, U3, and U4 and representing the seaward extent of structural compressional trends documented in the adjacent mainland. Axes of the antiformal and synformal structures are shown in Figure 3. Ravinement surface RS1 and Unit U5 fossilize these structures at the end of the Middle Pleistocene. Antiforms are slightly cut by normal faulting. 
A

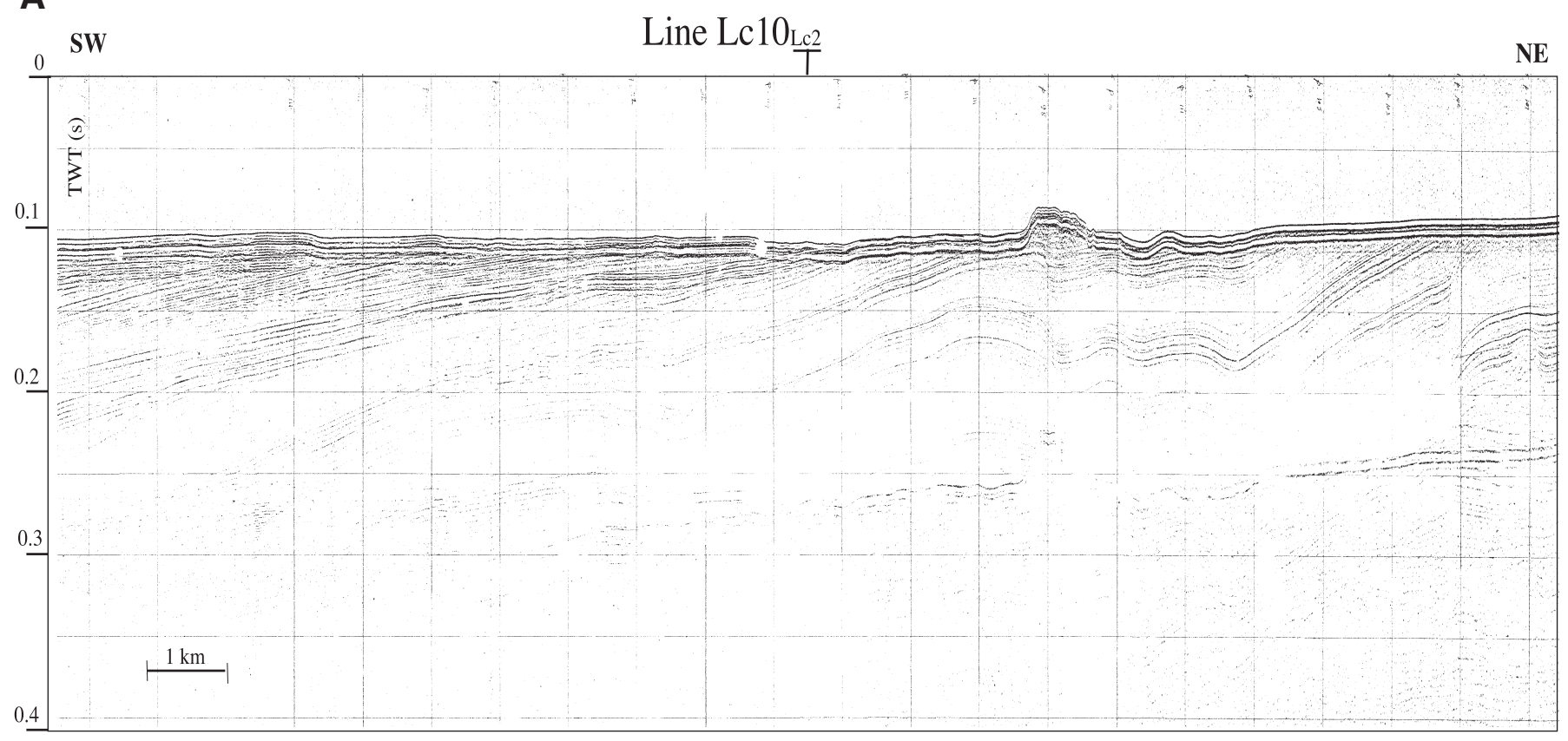

B

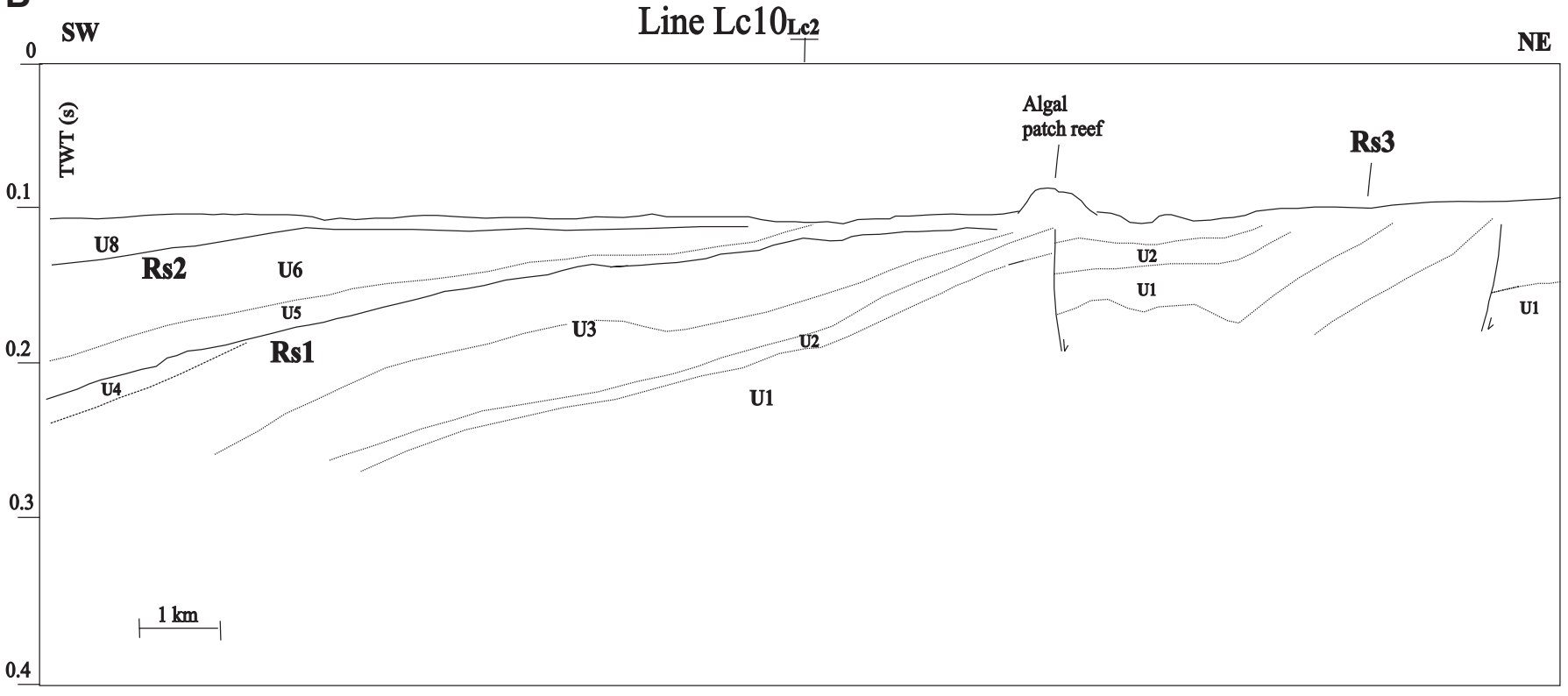

FIG. 7.-A) Seismic profile LC10 and B) corresponding interpretation (see Fig. 2 for location). The seismic profile and its interpretation show the Middle Pleistocene prograding wedge (seismic units U1-U4) truncated by ravinement surface RS1 and slightly deformed by normal faulting. Seismic units U5 and U6 overlie RS1 and are bounded in the uppermost part by RS2. Algal mounds have been recognized on ravinement surface RS3, cropping out at the sea bottom.

U6: progradational seismic unit conformably overlying the top of the unit U5 (Figs. 5, 6, and 7); two minor units (U6a and $\mathrm{U6b}$ ) were also distinguished (Fig. 5). In some sectors of the inner shelf, where unit U7 is not yet developed, unit U6 is directly truncated by ravinement surface RS2 (Fig. 7). There is paraconformity between the two units at the shelf margin (Fig. 13).
U7: progradational unit, conformably overlying the U6 seismic unit; in its upper part it is bounded by ravinement surface RS2 (Figs. 5, 6, 13). The unit is well developed at the shelf margin; on the contrary, in the inner part of the shelf unit U7 is missing and the underlying unit U6 is directly truncated by ravinement surface RS2 (Fig. 14). 


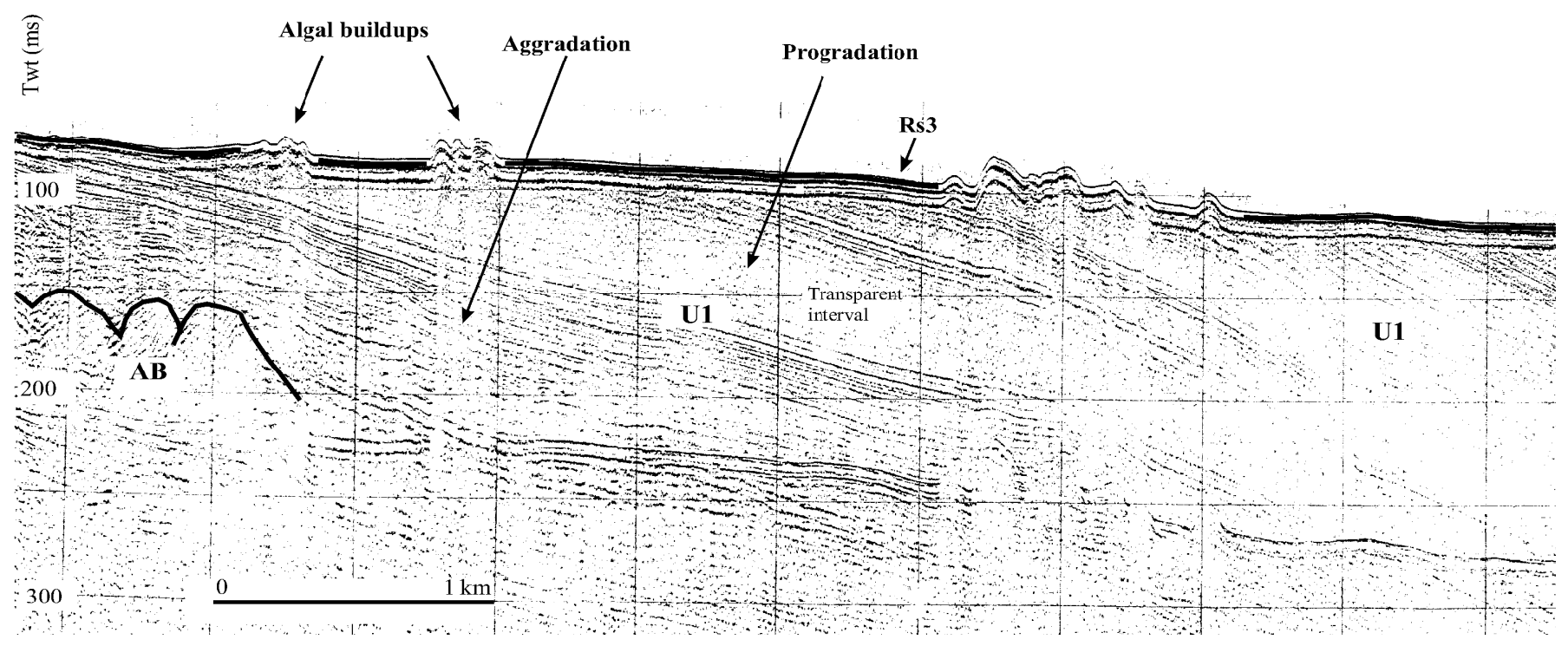

FIG. 8.-Seismic profile LC11 (see Fig. 2 for location), showing the geometry and the seismic facies of seismic unit U1. The seismic facies is characterized by the alternation of reflector packages with high amplitude and coherence and of acoustically transparent intervals. Note that the basal part of the unit shows mainly an aggradational component (on the left of the profile), whereas progradational geometries have been identified in the upper part of the unit (on the right of the profile).

U8: seismic unit located at the present-day shelf margin and characterized by reflectors onlapping RS2 and truncated by ravinement surface RS3 (Figs. 13, 14). The stratigraphic architecture of the unit is well shown in Figures 13 and 14. Here, five minor seismic units (U8a, U8b, U8c, U8d, and U8e) were identified by analysis of seismic facies. In the external part of the shelf margin the offlap breaks are well preserved and migrate progressively towards the shelf margin at increasing depths (Fig. 13). Chaotic intervals, probably corresponding to continental deposits filling incised valleys, formed during subaerial exposures of the shelf. They occur especially where the steepness of the reflectors increases and near the present-day shelf break (units U8d and U8e; Fig. 13). The top of Unit U8 is an erosional surface (RS3 in Figs. 5-9, 13, 14), developing with low gradients and eroding reflectors belonging to the underlying units up to the inner shelf. Ravinement surface RS3 coincides with the present-day sea bottom (Figs. 5-9, $13,14)$.

\section{INTERPRETATION}

A forced-regression systems tract, formed during phases of relative sea-level fall, was proposed by Hunt and Tucker(1992) as
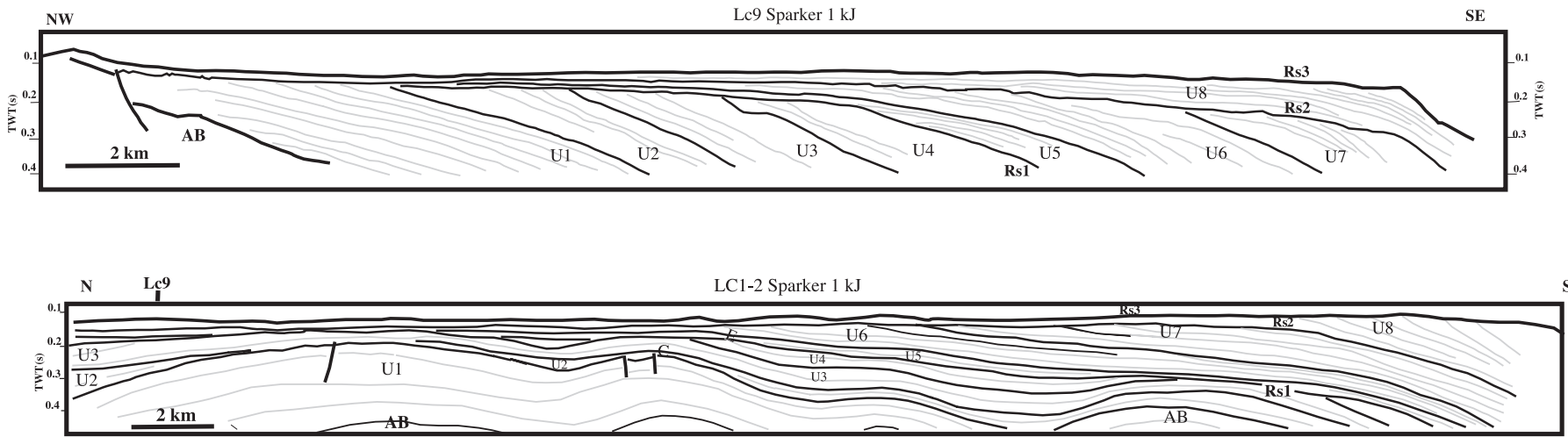

FIG. 9.--Regional seismic stratigraphy of the Salento continental shelf, as interpreted on the line drawings of seismic profiles LC9 (Fig. 5) and LC1-2 (Fig. 6). Both of the profiles show the stratigraphic relationships between the ravinement surfaces and the seismic units and are parallel (LC9 profile) and perpendicular (LC1-2 profile) to the progradation of wedges of the Salento shelf. The basal unit $(\mathrm{AB})$ is reported on both the regional line drawings. 


\section{Line Lc 1-2}

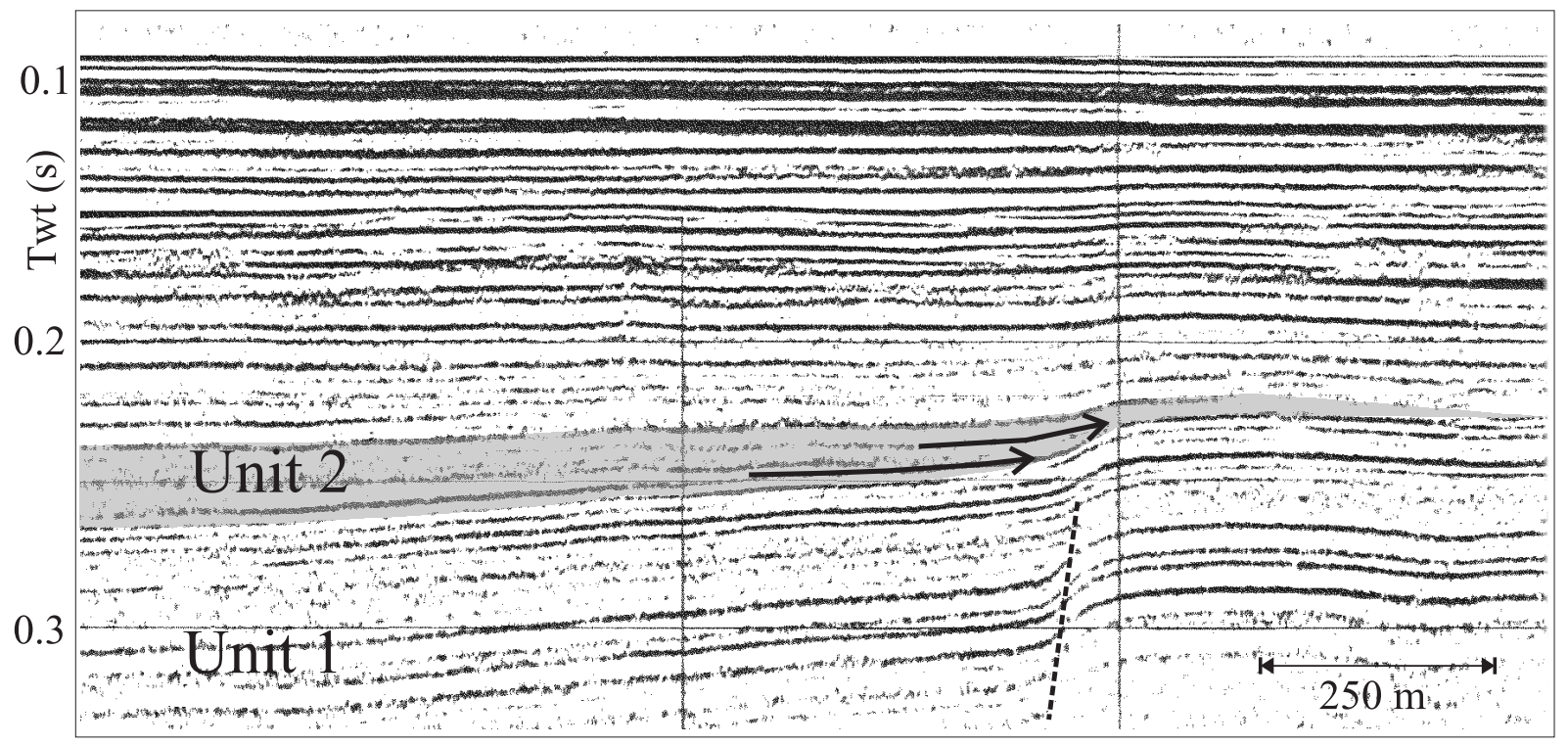

FIG. 10.-Detail of seismic line LC1-2 (see Fig. 2 for location and Figs. 6 and 9 for regional seismic stratigraphy of the units), showing onlap terminations of seismic unit $\mathrm{U} 2$ on the underlying unit U1.

a variation to the classical sequence-stratigraphic model, considering the relative abundance of lowstand prograding wedges in the stratigraphic architecture of the continental shelves. The parasequences, related to forced regressions, develop as a response to the decrease of the rate of sea-level fall; subsequently, they are "abandoned" and "isolated" when the rate of eustatic fall increases. The scientific debate mainly concerns the location of the sequence boundary. In the model of Hunt and Tucker (1992) the boundary is located above the forced-regression deposits, up to the point of maximum forced regression. In the classical model of sequence stratigraphy (Posamentier and Vail, 1988), it is located at the base of the lowstand "shelf-perched" prograding wedges (Tesson et al., 1993).

Polycyclic erosional surfaces sensu Posamentier and James (1993) often characterize the stratigraphic framework of continental shelf areas: they form during phases of relative sea-level

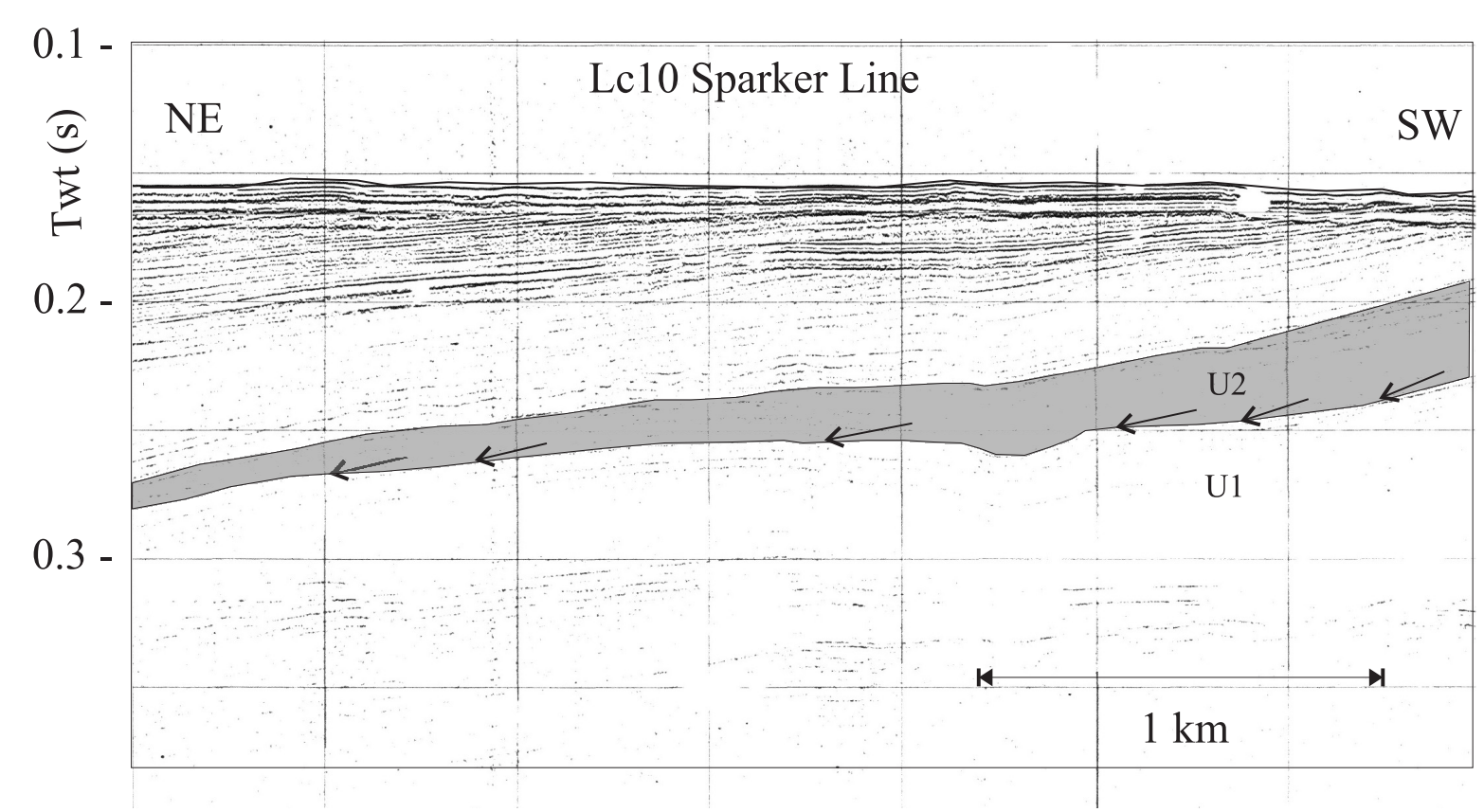

FIG. 11.-Detail of seismic line LC10 (see Fig. 2 for location and Fig. 7 for regional seismic stratigraphy of the units), showing downlap terminations of unit $\mathrm{U} 2$ on the underlying unit $\mathrm{U} 1$. 


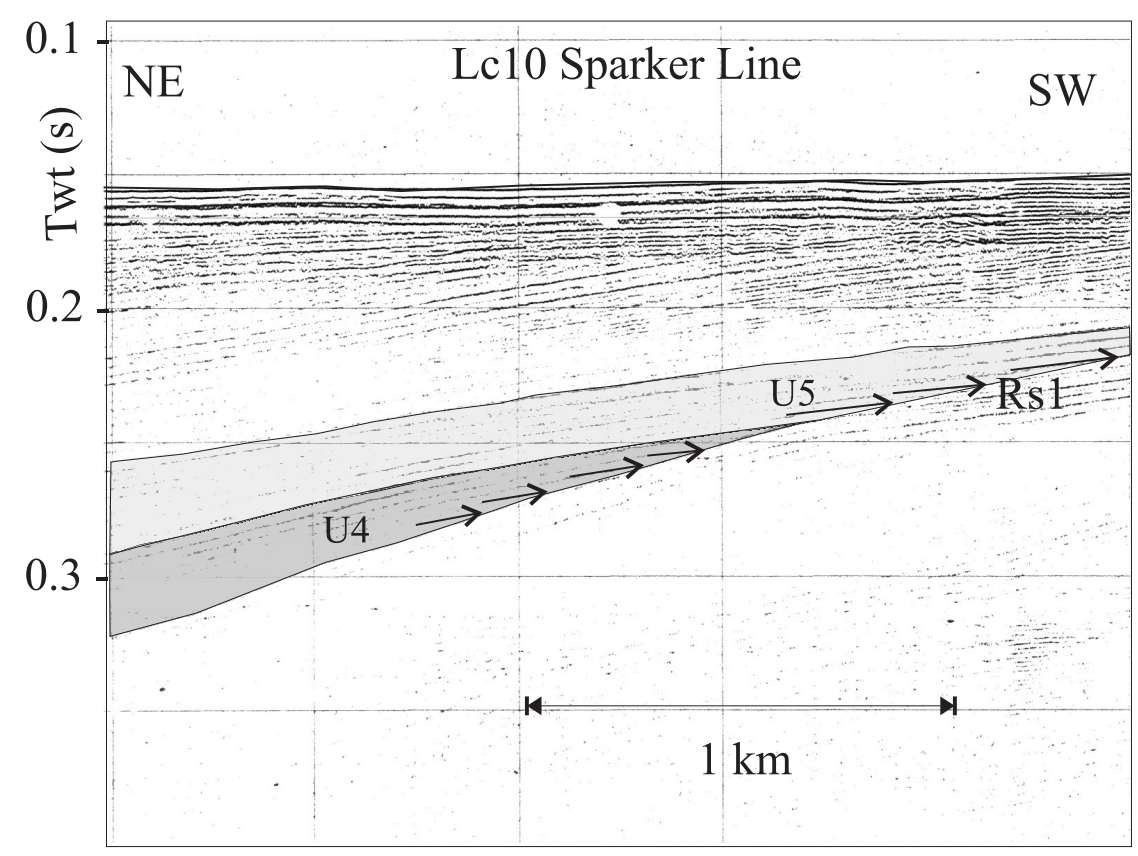

FIG. 12.-Detail of seismic line LC10 (see Fig. 2 for location and Fig. 7 for regional seismic stratigraphy of the units), showing onlap terminations of units U4 and U5 on ravinement surface RS1.

fall (lowstand surface of erosion) and are subsequently reworked during relative sea-level rise (ravinement surfaces). The frequent lack of transgressive paralic deposits, owing to their low thickness and poor potential for preservation, often forces the sequence boundaries to coincide with transgressive surfaces of erosion. These unconformities, namely the ravinement surfaces (Posamentier and James, 1993) develop because the erosional landward shift of the shoreline and their formation is due to reworking by wave action. The lowstand systems tract (LST) occurs between the sequence boundary and the ravinement surface only at the shelf margin (see also Fig. 5). The ravinement surface, marking the rise of sea level, represents the base of a marine succession characterized by parallel reflectors, diachronous in time, onlapping the underlying paralic sequence. When the paralic sequence is lacking, the ravinement surface coincides with the base of the transgressive systems tract. Then the ravinement surface (RS) and the transgressive surface (TS) are represented by the same unconformity, as in the study area (Correggiari et al., 1992; Trincardi et al., 1994; Budillon and Aiello, 1999; Trincardi and Correggiari, 2000; Ridente and Trincardi, 2002).

In the sedimentary sequence of the Salento continental shelf, several erosional unconformities are present, which outline the stratigraphic evolution of the area (Figs. 5-14). These surfaces are linked to large-scale erosional events and, on the basis of their geometry and depth, can be correlated at a regional scale along the Salento offshore.

The youngest ravinement surface (RS3; Figs. 5-9, 13, 14), which appears almost horizontal, has been observed at the sea bottom down to a maximum depth of -120 to $-130 \mathrm{~m}$, and only in the inner shelf has it been buried by the recent sediments of the Holocene wedge and by patch-reef structures, interpreted as relicts of algal buildups (Aiello et al., 1994; 1995). RS3 represents a main erosional surface, close to the physiographic shelf break, truncating the seismic reflectors of the prograding unit U8 (Figs. $5-9,13,14)$.
The second ravinement surface (RS2; Figs. 5-9, 13, 14) is observed down to a maximum depth of -175 to $180 \mathrm{~m}$ and develops landwards with higher gradients than RS3. The last surface truncates RS2 in the inner shelf and/or on structural highs (Fig. 7), eroding an onlapping sequence (unit U5 in Figs. 59) and the overlying prograding wedge, composed of the seismic units U6 and U7 (Figs. 5-9, 13).

Finally, the oldest ravinement surface (RS1; Figs. 5-9, 12) is observed down to a maximum of -180 to $-200 \mathrm{~m}$ of water depth and presents a well preserved paleo-shelf break (Fig. 5). On the inner shelf RS1 was eroded by RS2. Compressional deformation, which produced the antiformal and synformal structures shown in the Figures 6 and 9, affected the ravinement surface RS1. The wide prograding wedge, composed by seismic units U1, U2, U3, and U4 and bounded above by RS1 (Figs. 5, 9), has widened the Salento shelf by approximately fifteen kilometers (Fig. 3).

The steepness of the ravinement surfaces increases slightly from the youngest (RS3) to the oldest (RS1). This can be interpreted as an effect of the subsidence of the South Adriatic continental margin, due both to sediment loading and to compaction (Allen and Allen, 1990). However, part of this steepness enhancement may also be explained as an effect of tectonic subsidence, controlled by the regional evolution of the South Adriatic-Ionian bathyal plain (Moretti and Royden, 1987).

\section{DISCUSSION}

The concept of a ravinement surface in sequence stratigraphy is really powerful, because such a surface can be considered to be a stratigraphic marker, notwithstanding its diachronous character (Posamentier and James, 1993; Trincardi et al., 1994).

\section{Correlation to Oxygen Isotope Stratigraphy}

The ravinement surfaces and the seismic units of the Salento continental shelf can be correlated with isotope stratigraphy 


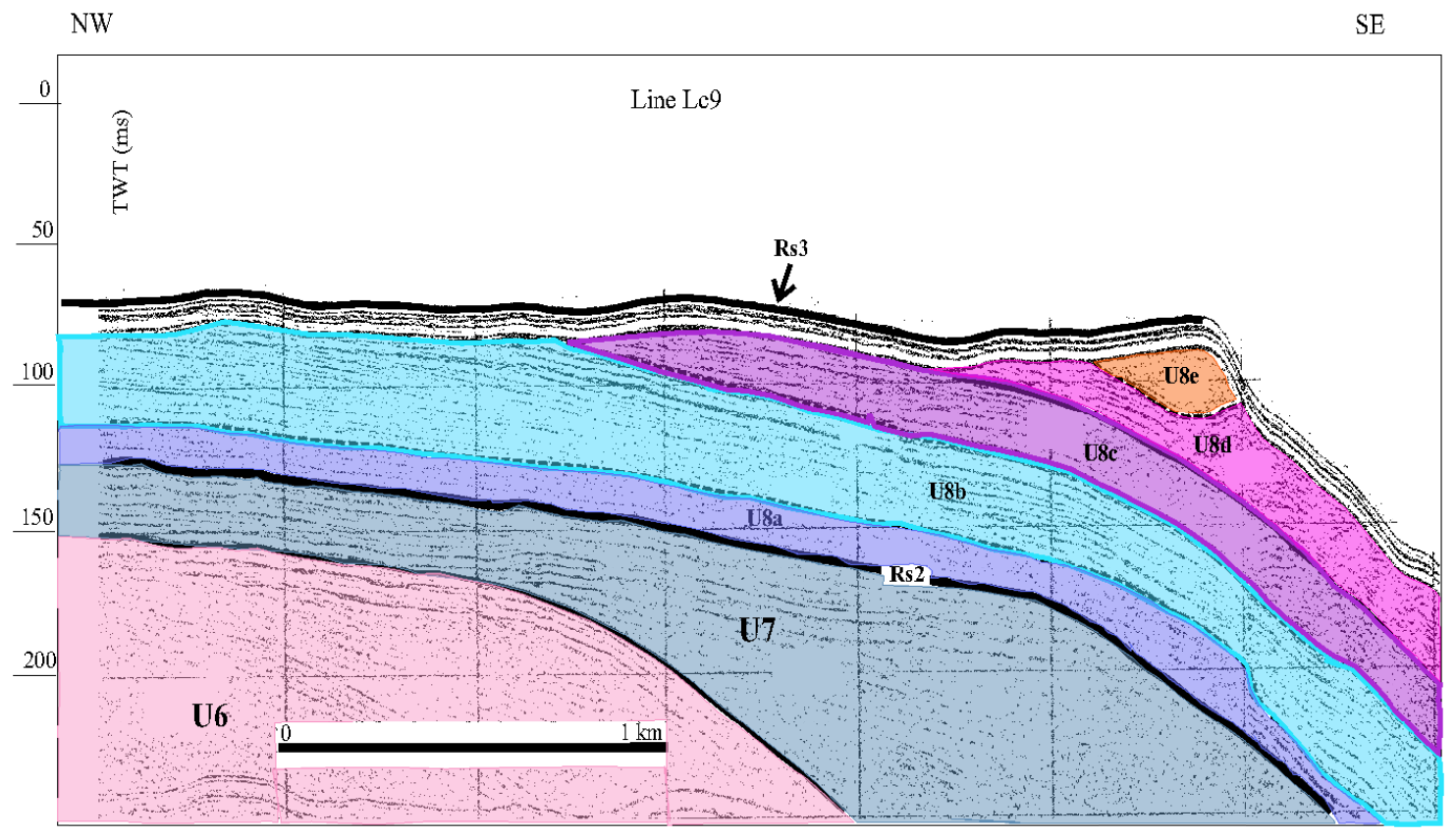

FIG. 13.-Detail of seismic line LC9 (see Fig. 2 for location and Figs 5 and 9 for regional seismic stratigraphy of the units), showing stratigraphic relationships between seismic units U6 and U7 at the shelf margin. The analytical seismic stratigraphic interpretation of the Late Pleistocene prograding wedge (Unit U8), bounded by ravinement surfaces RS2 and RS3, shows the presence of five seismic units (U8a, U8b, U8c, U8d, and U8e), interpreted as transgressive, lowstand, and forced-regression systems tracts.

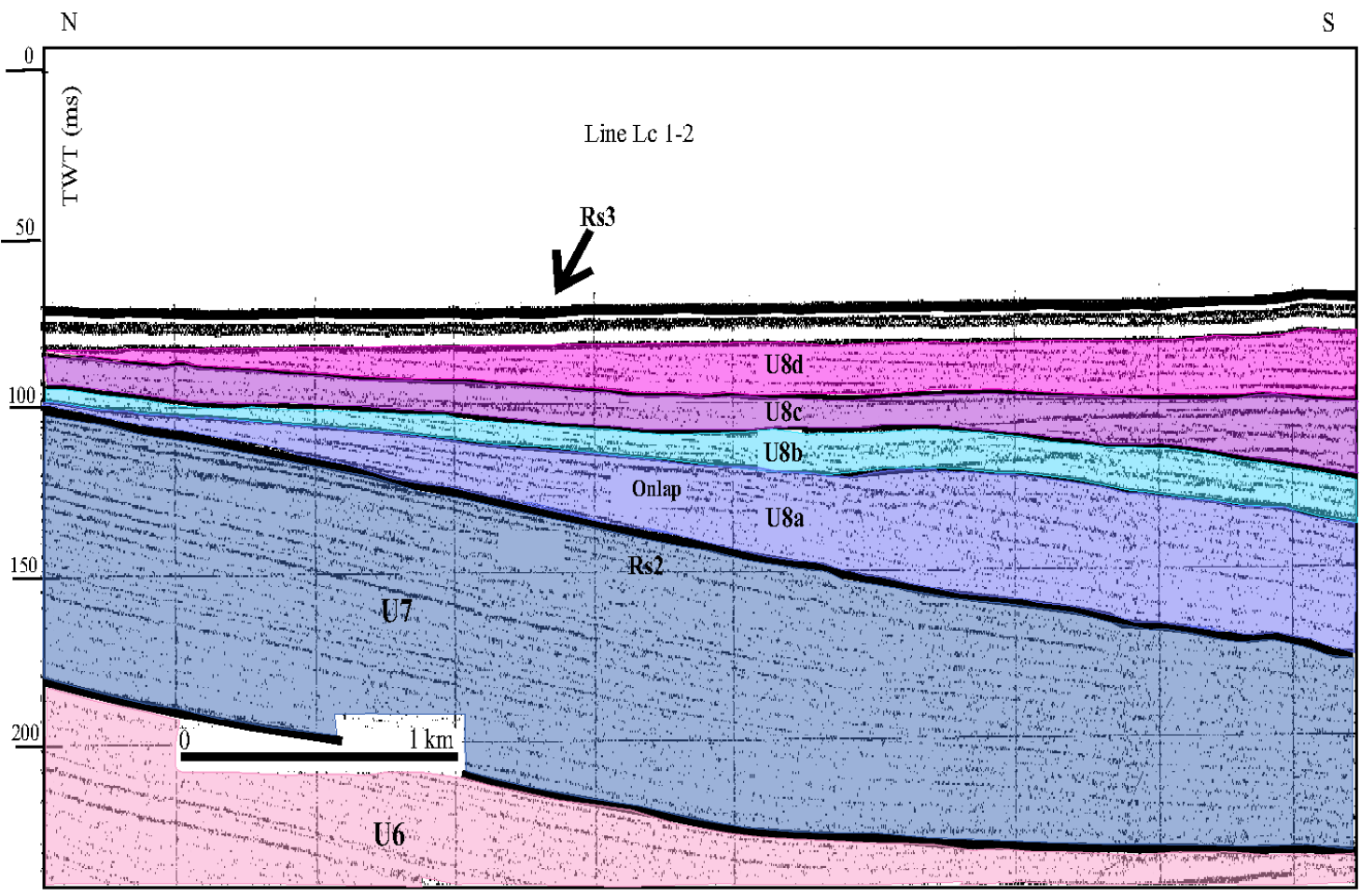

FIG. 14.-Detail of seismic line LC1-2, showing the onlap of Unit U8 on ravinement surface RS2 and the stratigraphic architecture of Unit U8 in the inner shelf. Note the lack of the minor seismic unit U8e, deposited only at the shelf margin, whereas Units U8aU8d appear well developed. 
because, starting from the Middle Pleistocene, they formed during relative sea-level rises, very rapid compared with the subsequent sea-level falls (Shackleton and Opdyke, 1973; Chappell and Shackleton, 1986; Martinson et al., 1987; Bard et al., 1990a; Bard et al., 1990b; Pirazzoli, 1993). In fact, the transgressive erosional unconformities formed during time intervals corresponding to the transition from even to odd stages on the isotopic curve. Accordingly, the isotope curve shows that, for the glacial Pleistocene, sea-level rise was very rapid and more or less comparable in amplitude to the most recent sea-level rise (about $120 \mathrm{~m}$; Bonifay, 1975), with periodicities of about $100 \mathrm{ky}$.

On the Salento shelf, we tentatively correlate the ravinement surfaces with the oxygen isotope stratigraphy of the last glacioeustatic cycle, as proposed by Martinson et al. (1987) and shown in Figure 15.

Ravinement surface RS3 (Figs. 5-9, 13, 14) was produced by the last significant sea-level rise, which developed from $18 \mathrm{ka}$ and is well known and documented along all of the Italian offshore (Borsetti et al., 1984; Marani et al., 1986; Chiocci et al., 1989; Colantoni et al., 1989). On the isotope curve it corresponds to the transition from stage 2 to stage 1 (Fig. 15); therefore we consider seismic unit U8b-U8e (Figs. 5, 13, 14) to have been formed during the last phases of the recent pleniglacial (isotope stages 3 and 2), and seismic unit U8a to represent a transgressive sequence (Fig. 5).

Ravinement surface RS2 (Figs. 5-9, 13, 14) formed during previous sea-level rise. For this rise the best choice considered is the transition from isotope stage 6 to 5 (Fig. 15). We support this interpretation for the clear continuity and conformity among the upper-slope units. Accordingly, the prograding wedge, limited in its uppermost part by ravinement surface RS3 and in its lowermost part by ravinement surface RS2 (corresponding to seismic unit U8 in Figs. 5-9, 13, 14), can be attributed to the Late Pleistocene. The minor seismic units distinguished in the wedge (seismic units U8b-U8e; Figs. 5, 13, 14) are here referred to forcedregression and lowstand systems tracts, whereas unit U8a is considered to represent a transgressive systems tract.

Finally, RS1 erodes a prograding wedge composed of units U1-U4 and is overlain by seismic unit U5, showing stacking patterns typical of a transgressive unit (Figs. 5-9). We consider RS1 to be due to a sea-level rise, antecedent to the rise suggested by RS2 and developing between isotope stages 8 and 7. This interval corresponds to a relative sea-level rise at about $250 \mathrm{ka}$ (Martinson et al., 1987). Therefore the seismic units from U1 to U4 are referred to forced-regression systems tracts.

On the basis of the above considerations we assume that during the Middle Pleistocene a fourth-order glacio-eustatic oscillation related to the short-eccentricity cycles controlled the deposition of the forced-regression systems tracts on the Salento continental shelf. Furthermore, geological and geomorphological evidence suggests appreciable rates of tectonic uplift of the Apulian foreland during the Early-Middle Pleistocene(Cosentino and Gliozzi, 1992; Doglioni et al., 1994). As a consequence, in the Middle Pleistocene the rate of tectonic uplift of the Apulian foreland prevailed over the rate of glacio-eustatic variation and produced a relative sea-level fall controlling the formation of a

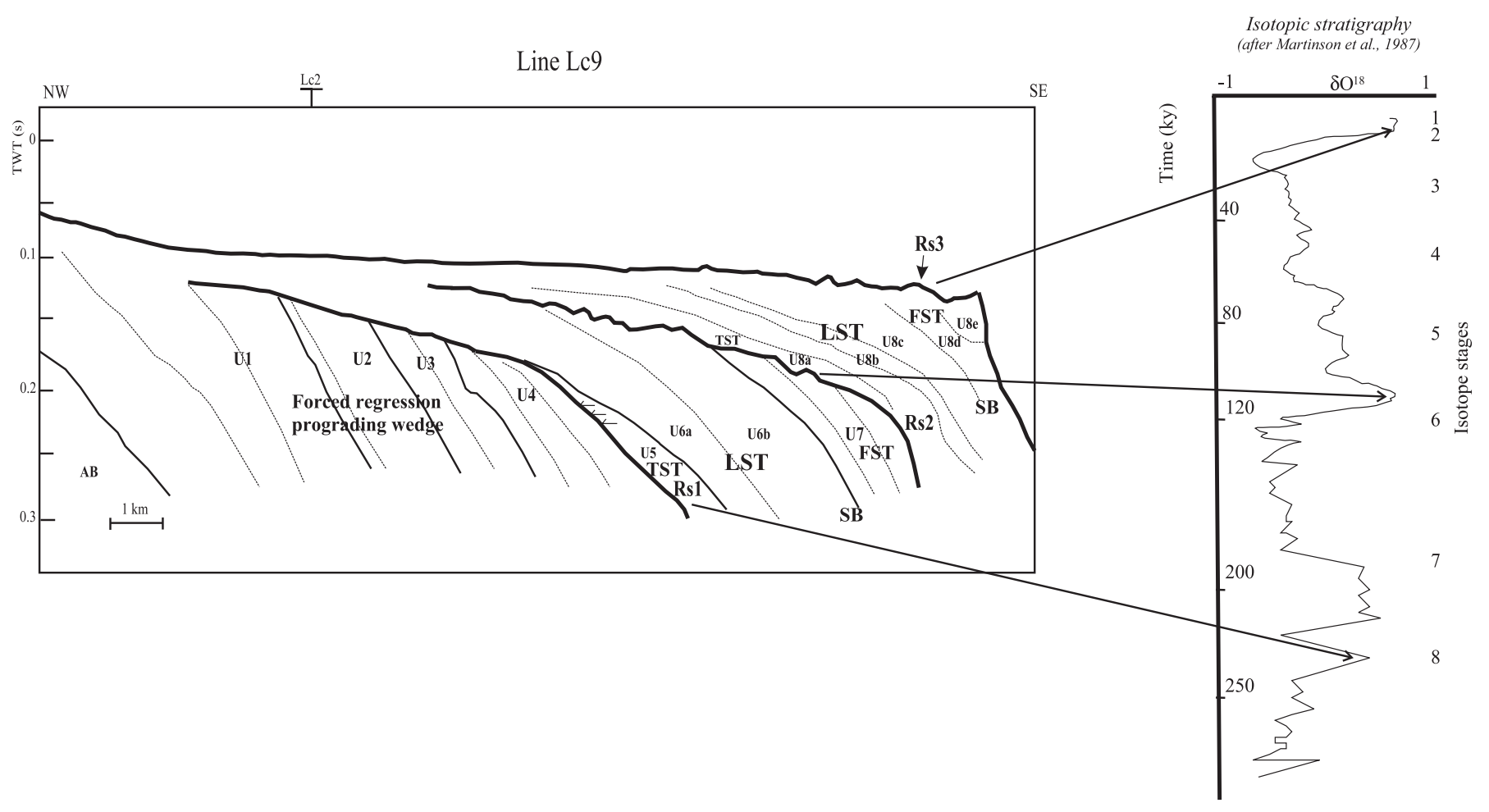

FIG. 15.-High-resolution stratigraphic correlation between the ravinement surfaces recognized in the Pleistocene succession of the Salento continental shelf and the curve of oxygen-isotope stratigraphy of the last glacio-eustatic cycle (Martinson et al., 1987). Unconformity RS1 is correlated with a sea-level rise at about $250 \mathrm{ka}$, corresponding to the transition from isotope stage 8 to 7. Unconformity RS2, overlying the Middle Pleistocene prograding wedge, is considered to correspond to the transition between isotope stages 6 and 5 and unconformity RS3, overlying the Late Pleistocene prograding wedge and corresponding to the transition from isotope stage 2 to 1 . 
forced-regression prograding wedge (seismic units U1, U2, U3, U4; Figs. 5-9, 10, 11, 12).

We now consider other implications of the seismostratigraphical architecture of the studied sections. Starting from RS1 (formed at about $250 \mathrm{ka}$ ) the depositional sequences consist not only of forced-regression deposits but also show a transgressive and lowstand systems tract. Transgressive systems tracts are very thin and composed of a single retrogradational parasequence (units U5 and U8a in Figs. 5-14), or they coincide with a transgressive surface of erosion, because of the starvation of the platform during the previous sea-level rise. Therefore, the transgressive systems tracts scarcely contributed in terms of thickness to the growth of the platform; instead they controlled the formation of important unconformities (ravinement surfaces; Posamentier and James, 1993), which are particularly evident when associated with asymmetric sea-level fluctuations, like those due to the short-eccentricity (fourth-order) cycles.

Starting at about $250 \mathrm{ka}$, geometries and stacking patterns suggest phases of rises and falls of relative sea level. Hence if the correlation of the RS surfaces with the curves of oxygen-isotope stratigraphy is consistent, the periodicity of the depositional sequences is about $100 \mathrm{ky}$ and is linked to short-term glacioeustatic cycles. Even if based on indirect dating of seismic units and corresponding unconformities, this correlation is well supported by the lateral extent and continuity of the ravinement surfaces, recognized in the whole investigated area. We note also that similar qualitative correlations of unconformities with tracts of the curves of oxygen-isotope stratigraphy have already been carried out by other authors, in different case histories of continental shelves of both active and passive margins in the same interval (Ashley et al., 1991; Okamura and Blum, 1993).

\section{Control Mechanisms}

The sedimentary supply feeding the forced-regression prograding wedge of the seismic units $\mathrm{U} 1, \mathrm{U} 2, \mathrm{U} 3$, and $\mathrm{U} 4$ is significantly rich, because it allowed a platform progradation of about fifteen kilometers (Fig. 3). Because a well developed river system was lacking in the Salento Peninsula, we suppose that the high sediment supply was due to the tectonic uplift affecting this area, lasted up to the Middle Pleistocene (Cosentino and Gliozzi, 1992; Doglioni et al., 1994). Moreover, antiformal and synformal structures shown by the LC1-2 profile (Figs. 6, 9), which deform units U1-U4, appear to be synsedimentary, as evidenced by the presence of growth structures in unit U2 (Figs. $6,9)$. On the basis of the correlation of these compressional trends with similar structures recognized onland in the Salento Peninsula by Bossio et al. (1988), we are led to think that the prograding wedge formed during the late Middle Pleistocene. All these observations also suggest that the mechanisms of onshore sequences and of contemporaneous development of the prograding wedge were very fast.

The upper-slope progradation could also have been fed by the biodetrital production in the inner shelf, whose resedimented materials may have contributed to form the prograding wedges.

Starting from seismic unit U5, onlapping RS1 and interpreted as a transgressive systems tract (Figs. 5-9), the eustatic control overwhelms the tectonic one, creating fourth-order incomplete depositional sequences. The sequences are incomplete because the stratigraphic record is fully preserved only at the shelf margin; behind this margin we observe only transgressive, forcedregression, and lowstand systems tracts. In the wedge between RS1 and RS2 (Figs. 5-9), Unit U5 represents a transgressive systems tract, bounded above by a sequence boundary, whereas Unit U6 forms a forced-regression systems tract and Unit U7 a lowstand systems tract. Moreover, in the wedge between RS2 and RS3 (seismic Unit U8; Figs. 5-9, 13, 14) Unit U8a is interpreted as a transgressive systems tract (Fig. 5), Units U8b and U8c are read as a forced regression systems tract, bounded above by the sequence boundary, and Units U8d and U8e are interpreted as a lowstand systems tract, where chaotic deposits have also been identified (Fig. 5).

In conclusion, eustatic control on the stratigraphic architecture of the Late Pleistocene wedge is supported by the correlation of RS1, RS2, and RS3 with the curve of isotope stratigraphy (Fig. 15). Accordingly a fourth-order cyclicity with a periodicity of about $100 \mathrm{ky}$ (short-eccentricity cycles), which may have controlled the formation of fourth-order incomplete depositional sequences (seismic Units U5-U8 in Figs. 5-9, 13, 14), is inferred and related to the oxygen isotope stages from $7 / 8$ to 2 (Martinson et al., 1987).

Quaternary forced-regression deposits formed in response to fourth-order (100 ky) cyclicity have been also investigated in the Central Adriatic basin (Trincardi et al., 1994; Trincardi and Correggiari, 2000; Ridente and Trincardi, 2002) and a composite nature of oscillation cycles of relative sea level, where a longerterm relative sea-level rise interacted with the shorter-term (fourthto fifth-order) sea-level cycles, has been suggested in order to explain the formation of forced-regression deposits and their preservation (Trincardi and Correggiari, 2000). The progradational units recorded a fourth-order Quaternary cyclicity in which transgressive erosional surfaces punctuated the stratigraphic record with a periodicity of about $100 \mathrm{ky}$ during isotope stage boundaries $2 / 1,6 / 5,8 / 7,10 / 9$, and 12/11, as suggested also by core analysis (Trincardi and Correggiari, 2000).

\section{CONCLUSIONS}

1. The Salento continental shelf is an example of complex stratigraphic architecture of Pleistocene prograding wedges, recording the effects of eustatic oscillation of sea level and of changes in rate of sedimentation, driven by tectonic activity in the source zone. Moderate deformation in the depositional areas does not obscure the eustatic signal.

2. In the stratigraphic sequence analyzed, three ravinement surfaces were recognized, extending landwards from the shelf break and showing low gradients. The three ravinement surfaces (RS1, RS2, and RS3) have been considered to be stratigraphic markers and correlated to the curves of oxygenisotope stratigraphy (Martinson et al., 1987).

3. The regional geological framework suggests that, during the Middle Pleistocene, tectonic uplift of the Apulian foreland interacted with high-frequency fourth-order glacio-eustatic fluctuations, producing the deposition of forced-regression systems tracts. A wide forced-regression prograding wedge (Units U1-U4), deposited during the Middle Pleistocene, enlarged the Salento shelf by about 15 kilometers (Fig. 3).

4. During the Late Pleistocene-Early Holocene, glacio-eustatic sea-level changes with a periodicity of about $100 \mathrm{ky}$ controlled the stratigraphic architecture of the Salento continental shelf, creating fourth-order incomplete depositional sequences in the two upper prograding wedges (Units U5-U7, bounded in their uppermost part by ravinement surface RS2 and in its lowermost part by ravinement surface RS1; Unit U8, bounded in its uppermost part by ravinement surface RS3 and in its lowermost part by ravinement surface RS2). Deposition of forced-regression (seismic units U6, U8b-U8c), lowstand (seis- 
mic units U7 and U8d-U8e) and transgressive (seismic units U5 and U8a) systems tracts, which were distinguished in the two incomplete depositional sequences, is controlled by fourthorder glacio-eustasy modulated by short-eccentricity cycles of the Earth's orbit.

5. The eustatic signal, overwhelming with respect to the tectonic one, suggests a decrease in the rate of uplift of the Apulian foreland during the last $250 \mathrm{ky}$.

\section{ACKNOWLEDGMENTS}

This work was carried out with the financial contribution of the Istituto per l'Ambiente Marino Costiero, IAMC, National Research Council, Naples, Italy (formerly Geomare sud). We wish to thank the colleagues participating in the GMS94-01 oceanographic cruise (R/V Urania, CNR, Italy), during which seismic profiles interpreted in this paper were recorded. We thank Prof. Bruno D'Argenio and Prof. Vittoria Ferreri (Dipartimento di Scienze della Terra, Università degli Studi di Napoli "Federico II", Naples, Italy) for suggestions at different steps of the manuscript preparation. We also thank the two referees, Dr. Bernard Gensous (Université de Perpignan, CEFREM, Perpignan, France) and Prof. Francesco Latino Chiocci (Università di Roma "La Sapienza", Rome, Italy) for their very helpful observations, allowing a significant improvement of the paper. Finally, we thank Patricia Sclafani (CNR-IAMC, Naples, Italy) for reviewing the English.

\section{REFERENCES}

Aiello, G., Bravi, S., Budillon, F., Caruso, A., D'Argenio, B., De Lauro, M., Ferraro, L., Marsella, E., Molisso, F., Pelosi, N., Sacchi, M., Toscano, F., AND TRAMONTANO, M.A., 1994, La piattaforma continentale pugliese al largo di Brindisi e tra Capo d'Otranto e S. Maria di Leuca (Adriatico meridionale): Approccio ad uno studio integrato di geologia marina: Istituto di Ricerca "GeomareSud", National Research Council, Napoli, Italy, Technical Report no. 2, 25 p.

Aiello, G., Bravi, S., Budillon, F., Caruso, A., D' Argenio, B., De Lauro, M., Ferraro, L., Marsella, E., Molisso, F., Pelosi, N., Sacchi, M., Toscano, F., and Tramontano, M.A., 1995, Marine Geology of the Salento shelf (Apulia, south Italy): preliminary results of a multidisciplinary study: Giornale di Geologia, v. 57 (1-2), p. 17-40.

Allen, P.A., And Allen, J.R., 1990, Basin Analysis; Principles and Applications: Oxford, U.K., Blackwell Scientific Publications, 451 p.

Ashley, G.M., Wellner, R.W., EsKer, D., AND SHeridan, R.E., 1991, Clastic sequences developed during late Quaternary glacio-eustatic sealevel fluctuations on a passive margin: Example from the inner continental shelf, Barnegat Inlet, New Jersey: Geological Society of America, Bulletin, v. 103, p. 1607-1621.

Bard, E., Hamelin, B., And FairbanKs, R.G., 1990a, U-Th ages obtained by mass spectrometry in corals from Barbados: sea-level during the past 130,000 years: Nature, v. 346, p. 456-458.

Bard, E., Labeyrie, L.D., Pichon, J.J., Labracherie, M., Arnold, J., Duprat, J., Moyes, J., AND Duplessy, J.C., 1990b, The last deglaciation in the southern and northern hemispheres: a comparison based on oxygen isotopes, sea surface temperatures estimates and accelerator ${ }^{14} \mathrm{C}$ dating from deep-sea sediments, in Bleil, U., and Thiede, J., eds., Geological History of the Polar Oceans: Arctic versus Antarctic: Boston, Kluwer Academic, p. 405-416.

BonIfAY, E., 1975, L'Ere Quaternaire: définition, limites and subdivision sur la base de la chronologie Méditerrannée: Société Géologique de France, Bulletin, v. 17, p. 380-393.

Borsetti, A., Loik, L., AND Colantoni, P., 1984, Variazioni nella sedimentazione al passaggio glaciale-postglaciale e Olocene in alcuni bacininord-tirrenici evidenziate dal contenuto microfaunistico:Società Geologica Italiana, Memorie, v. 27, p. 323-332.

Bossio, A., Guelfi, F., Mazzei, R., Monteforti, B., and Salvatorini, G., 1988, Studi sul Neogene ed il Quaternario della Penisola Salentina, VNote geologiche sulla zona di Castro: Final Proceedings of the Conference "Conoscenze Geologiche della Penisola Salentina", Lecce, Italy, Facoltà di Ingegneria di Lecce, Quaderni Geotecnici, v. 11, p. 127-145.

Budillon, F., And Aiello, G., 1999, Evoluzione pleistocenica della piattaforma continentale del Salento orientale: fattori di controllo tettonici e/o eustatici: Il Quaternario, v. 12 (2), p. 149-160.

Catalano, R., Di Stefano, E., Sulli, A., Vitale, F.P., Infuso, S., and Vail, P.R., 1998, Sequences and system tracts calibrated by high-resolution bio-chronostratigraphy: the central Mediterranean Plio-Pleistocene record, in de Graciansky, P.C., Hardenbol, J., Jacquin, T., and Vail, P.R., eds., Mesozoic and Cenozoic Sequence Stratigraphy of European Basins: SEPM, Special Publication 60, p. 155-177.

Chappell, J., AND SHACKLETON, N.J., 1986, Oxygen isotopes and sea level: Nature, v. 324, p. 137-140.

Chiocci, F.L., D’ Angelo, S., Orlando, L., And Pantaleone, A., 1989, Evolution of the Holocene shelf sedimentation defined by high-resolution seismic stratigraphy and sequence analysis (Calabro-Tyrrhenian continental shelf): Società Geologica Italiana, Memorie, v. 48, p. 359-380.

ChIOcCI, F.L., ERcilla, G., AND ToRres, J., 1997, Stratal architecture of western Mediterranean margin as the result of the stacking of Quaternary lowstand deposits below "glacio-eustatic fluctuation base-level": Sedimentary Geology, v. 112, p. 195-217.

Ciaranfi, N., Pieri, P., And Ricchetti, G., 1992, Note alla carta geologica delle Murge e del Salento (Puglia centro-meridionale): Società Geologica Italiana, Memorie, v. 41, p. 449-460.

Colantoni, P., Gallignani, P., and Lenaz, R., 1989: Late Pleistocene and Holocene evolution of the North Adriatic continental shelf (Italy): Marine Geology, v. 33, p. 41-50.

Correggiari, A., Roveiri, M., And Trincardi, F., 1992, Regressioni “forzate", regressioni deposizionali e fenomeni di instabilità in unità progradazionali tardo-quaternaire (Adriatico centrale): Giornale di Geolgia, v. 54, p. 19-36.

Cosentino, D., AND GLIozzI, E., 1992, Considerazioni sulla velocità di sollevamento dei depositi eutirreniani dell'Italia meridionale e della Sicilia: Società Geologica Italiana, Memorie, v. 41, p. 653-665.

D' Argenio, B., Pescatore, T., ANd Scandone, P., 1973, Schema geologico dell'Appennino meridionale (Campania e Lucania): Final Proceedings of the Conference "Moderne vedute sulla Geologia dell'Appennino", Accademia Nazionale dei Lincei, v. 183, p. 4972.

Doglioni, C., Mongelli, F., And Pieri, P., 1994, The Puglia uplift: an anomaly of the foreland of the Apenninic subduction due to the buckling of a thick continental lithosphere: Tectonics, v. 13, p. 13091321.

FaIRBANKS, R.G., AND MatTHEWS, R.K., 1978, The marine oxygen isotope record in Pleistocene coral, Barbados: Quaternary Research, v. 10, p. 181-196.

FIELD, M.E., AND TRINCARDI, F., 1992, Regressive coastal deposits on Quaternary continental shelves: preservation and legacy, in Osborne, R.H., ed., From Shoreline to Abyss: Contributions in Marine Geology in Honor of Francis Parker Shepard: SEPM, Special Publication 46, p. 107-122.

Gensous, B., Williamson, D., And Tesson, M., 1993, Late Quaternary transgressive and highstand deposits on a deltaic shelf (Rhone delta, France), in Posamentier, H.W., Summerhayes, C.P., Haq, B.U., and Allen, G.P., eds., Sequence Stratigraphy and Facies Associations: International Association of Sedimentologists, Special Publication 18, p. 197-211.

HeARTY, P.J., AND DAI PRA, G., 1992, The age and stratigraphy of middle Pleistocene and younger deposits along the Gulf of Taranto (southeast Italy): Journal of Coastal Research, v. 8, p. 882-905. 
HunT, D., AND TUCKER, M.E., 1992, Stranded parasequences and the forced regression wedge system tract: deposition during base-level fall: Sedimentary Geology, v. 81, p. 1-9.

Marani, M., Taviani, M., Trincardi, F., Argnani, A., Borsetti, A., AND ZiTELLINI, N., 1986, Pleistocene progradation and postglacial events on the tyrrhenian continental shelf between the Tiber river delta and Capo Circeo: Società Geologica Italiana, Memorie, v. 36, p. 67-89.

Martinson, D.G., Pisias, N.G., Hays, J.D., Imbrie, J., Moore, T.C., and Shackleton, N.J., 1987, Age dating and the orbital theory of the ice ages: development of a high-resolution 0 to 300,000 year chronostratigraphy: Quaternary Research, v. 27, p. 1-29.

Mitchum, R.M., VAIL, P.R., AND SANGREe, J.M., 1977, Seismic stratigraphy and global change of sea level, Part 6: Stratigraphic interpretation of seismic reflection patterns in depositional sequences, in Payton, C.E., ed., Seismic Stratigraphy-Applications to Hydrocarbon Exploration: American Association of Petroleum Geologists, Memoir 26, p. $117-133$.

MoretTI, I., AND Royden, L., 1987, Deflection, gravity anomalies and tectonics of doubly subducted continental lithosphere: Adriatic and Ionian seas: Tectonics, v. 7, p. 875-893.

OKAMURA, Y., AND Blum, P., 1993, Seismic stratigraphy of Quaternary stacked depositional sequences in the Southwest Japan forearc: an example of fourth order sequences of an active margin, in Posamentier, H.W., Summerhayes, C.P., Haq, B.U., and Allen, G.P., eds., Sequence Stratigraphy and Facies Associations: International Association of Sedimentologists, Special Publication 18, p. 213-232.

PIrazzoli, P.A., 1993, Global sea level changes and their measurement: Global and Planetary Change Letters, v. 8, p. 135-148.

Posamentier, H.W., AND Vail, P.R., 1988, Eustatic control on clastic deposition II-sequence and system tract models, in Wilgus, C.K., Hastings, B.S., Kendall, C.G.St.C., Posamentier, H.W., Ross, C.A., and Van Wagoner, J.C., Sea Level Changes: An Integrated Approach: SEPM, Special Publication 42, p. 125-154.

Posamentier, H.W., AND James, D.P., 1993, An overview of sequence stratigraphic concepts: uses and abuses, in Posamentier, H.W., Summerhayes, C.P., Haq, B.U., and Allen, G.P., eds., Sequence Stratigraphy and Facies Associations: International Association of Sedimentologists, Special Publication 18, p. 3-18.

Posamentier, H.W., Allen, G.P., James, D.P., and Tesson, M., 1992, Forced regression in a sequence stratigraphic framework: concepts, examples, and exploration significance: American Association Petroleum Geologists, Bulletin, v. 76, p. 1687-1709.

Ricchetti, G., Ciaranfi, N., Luperto Sinni, E., Mongelli, F., and Pieri, P., 1992, Geodinamica ed evoluzione stratigrafico-tettonica dell'avampaese apulo: Società Geologica Italiana, Memorie, v. 42, p. 287-300.
Ridente, D., AND Trincardi, F., 2002, Late Pleistocene depositional cycles and syn-sedimentary tectonics on the central and south Adriatic shelf: Società Geologica Italiana, Memorie, v. 57, p. 517-526.

SAITO, Y., 1991, Sequence stratigraphy on the shelf and the upper slope in response to the latest Pleistocene-Holocene sea level changes off Sendai, northeast Japan, in McDonald, D.I.M., ed., Sedimentation, Tectonics, and Eustasy: Sea-Level Changes at Active Margins: International Association of Sedimentologists, Special Publication 12, p. 133-150.

ShaCKLETON, N.J., AND OpdyKe, N.D., 1973, Oxygen isotope and paleomagnetic stratigraphy of equatorial Pacific core V28-238: oxygen isotope temperature and ice volume on a 10 year scale: Quaternary Research, v. 3, p. 39-55.

SUTER, J.R., AND BERRYHILL, H.L., 1985, Late Quaternary shelf margin deltas, northwest Gulf of Mexico. American Association of Petroleum Geologists, Bulletin, v. 69, p. 77-91.

Suter, J.R., Berryhill, H.L., AND Penland, S., 1987, Late Quaternary sealevel fluctuations and depositional sequences, southwest Louisiana continental shelf, in Nummedal, D., Pilkey, O.H., and Howard, J.D., eds., Sea-Level Fluctuation and Coastal Evolution: SEPM, Special Publication 41, p. 199-219.

Tesson, M., Gensous, B., Allen, G.P., and Ravenne, C., 1990, Late Quaternary deltaic lowstand wedges on the Rhone continental shelf, France: Marine Geology, v. 91, p. 325-332.

Tesson, M., Allen, G.P., and Ravenne, C., 1993, Late Pleistocene shelf perched lowstand wedges on the Rhone continental shelf, in Posamentier, H.W., Summerhayes, C.P., Haq, B.U., and Allen, G.P., eds., Sequence Stratigraphy and Facies Associations: International Association of Sedimentologists, Special Publication 18, p. 183-196.

TRINCARDI, F., AND Field, M.E., 1991, Geometry, lateral variation and preservation of downlapping regressive shelf deposits: Eastern Tyrrhenian sea margin, Italy: Journal of Sedimentary Petrology, v. 61, p. 775-790.

Trincardi, F., Correggiari, A., AND Roveri, M., 1994, Late Quaternary transgressive erosion and deposition in a modern epiconental shelf: the Adriatic semienclosed basin: Geomarine Letters, v. 14, p. 41-51.

TRINCARDI, F., AND CoRREGGiarI, A., 2000, Quaternary forced regression deposits in the Adriatic basin and the record of composite sea-level cycles, in Hunt, D., and Gawthorpe, R.L., eds., Sedimentary Responses to Forced Regressions: Geological Society of London, Special Publication 172, p. 245-269.

Vail, P.R., Audemard, F., Bowman, S.A., Eisner, P.N., and Perez Cruz, C., 1991, The stratigraphic signatures of tectonics, eustacy and sedimentology-an overview, in Einsele, G., Ricken, W., Seilacher, A., eds., Cycles and Events in Stratigraphy: Berlin, Springer-Verlag, p. 617659. 